This PDF is a selection from an out-of-print volume from the National Bureau of Economic Research

Volume Title: Tax Policy and the Economy, Volume 12

Volume Author/Editor: James M. Poterba, editor

Volume Publisher: MIT Press

Volume URL: http://www.nber.org/books/pote98-1

Publication Date: January 1998

Chapter Title: Would a Consumption Tax Reduce Interest Rates?

Chapter Author: Martin Feldstein

Chapter URL: http://www.nber.org/chapters/c10917

Chapter pages in book: (p. $173-253)$ 


\section{WOULD A CONSUMPTION TAX REDUCE INTEREST RATES?}

\section{Martin Feldstein}

Harvard University and NBER

\section{EXECUTIVE SUMMARY}

Although there is substantial professional and public interest in the recent proposals to replace the existing personal and corporate income taxes with a consumption tax, there has been little attention to the effect of such a tax change on pre-tax interest rates and other pre-tax factor incomes. Despite the general absence of formal analyses, some economists have concluded that shifting to a consumption-type tax would lead, because such a tax would exempt interest income and encourage additional saving, to lower pre-tax interest rates.

The most widely cited such statement is by Hall and Rabushka (1995), who say that long-term interest rates would decline by 20 percent if the existing U.S. tax system were replaced by a consumption tax of the type that they advocate. ${ }^{1}$ Hall (1996) presents the only formal analytic model of the effect on the interest rate of shifting to a consumption tax. His analysis deals with an economy of infinite-lived individuals in which the net-of-tax interest rate would be a constant determined by the time preference pa-

The author is a professor of economics at Harvard University, and the President of the National Bureau of Economic Research. He is grateful to Erzo Luttmer for research assistance and discussions. A more technical version of this paper appears in Feldstein (1995b). Each section of that paper provides a more formal algebraic demonstration of the statements in the corresponding section of the current paper.

1 Toder (1995) also concludes that any shift to a consumption-type tax would be likely to reduce real interest rates. 
rameter of the representative individual. Eliminating the interest income tax in such an economy would therefore reduce the pre-tax interest rate to the equilibrium net interest rate.

In this paper, I explain why the opposite may well be true: substituting a consumption tax for the existing personal and corporate income taxes may raise pre-tax interest rates. The analysis indicates that whether the pre-tax rate of interest rises or falls depends on the strength of the personal saving response and the nature of the capital-market relation between debt and equity yields. With plausible parameter values, the analysis suggests that the shift from an income tax to a consumption tax is more likely to raise interest rates than to lower them. ${ }^{2}$

An important common feature of all the current consumption-tax proposals is to eliminate the tax on corporate profits. Corporations would, under some proposals, continue to make tax payments, but the tax collected from the corporations would become either a tax on the firm's non-cash labor compensation or a consumption-type value-added tax. ${ }^{3}$ The failure to take the elimination of the corporate tax into account has led much of the discussion of consumption taxes to wrong conclusions about the impact on interest rates of shifting to a consumption tax. ${ }^{4}$

Although there appear to be several different types of consumption taxes-consumed income taxes that permit a deduction for all net saving but continue to tax investment income, taxes that exclude investment income but do not allow a deduction for saving, value-added taxes, and national retail sales taxes-all of these different variants are in fact equivalent in the sense that after the transition they all define the same consumption opportunities for individuals who have the same wage income (i.e., they imply the same lifetime budget constraints). This equivalence is demonstrated explicitly in Appendix A to this paper. The paper itself uses the term consumption tax to refer to a tax that excludes all investment income at the corporate and personal level, but exactly the same conclusions would follow for a consumed-income tax, a national retail sales tax, or a value-added tax.

The paper begins in section 1 by discussing the effect that shifting from the existing income-tax system to a consumption tax would have on the rate of interest if individual saving remained unchanged. Section

2 Bradford (1995) notes that the effect of a consumption tax on the rate of interest depends on the relative elasticities of the supply of capital and the demand for capital.

${ }^{3}$ As noted in footnote 4, the Hall-Rabushka tax paid by companies is a tax on noncash labor compensation.

${ }^{4}$ Neither Hall (1996) nor Bradford (1995) deals with the effect of eliminating the corporate income tax. 
2 then extends the analysis to an economy in which the saving rate responds to changes in the net of tax rate of interest. The analysis of these two sections emphasizes that the shift to a consumption tax would eliminate the corporate tax on investment income as well as the personal tax on interest and dividends. Eliminating the corporate tax raises the capital income available at the company level to pay interest and dividends. Section 3 examines the sensitivity of the results to the assumed relation between debt and equity yields. Section 4 introduces the role of inflation. The fifth section then brings together these separate analyses to discuss the effects of changing the tax structure in a growing economy with inflation and with interest-sensitive saving behavior. There is a brief concluding section that comments on the generalization of this analysis to recognize international capital flows and different types of domestic borrowers and lenders.

\section{THE EFFECT OF A CONSUMPTION TAX WITH A FIXED CAPITAL STOCK 5}

This section considers how shifting from the existing personal and corporate income taxes to a consumption tax would alter the equilibrium rate of interest and the net return to savers in a simplified setting with a fixed capital stock employed in the corporate sector and a zero rate of inflation. ${ }^{6}$ The fixed capital stock in this one-sector economy implies that the corporate borrowers earn a fixed pre-tax marginal product of capital. Under the current tax rules, the company's taxable income is equal to the marginal product of capital (net of depreciation) minus the interest payments made to the providers of debt capital. ${ }^{7}$ The return net of taxes and of interest payments is then available for the equity owners of the company, either as dividends or as retained earnings.

Eliminating the corporate income tax raises the funds available to the providers of both debt and equity capital. If the rate of interest remained unchanged, all of the corporate tax reduction would accrue to the provid-

${ }^{5}$ Appendix $\mathrm{B}$ of this paper presents an explicit algebraic statement of this section and a derivation of the effect of changes in personal and corporate tax rates on the pre-tax rate of interest.

6 The analysis also simplifies by ignoring the special tax rules that now apply to pensions and individual retirement accounts. For many taxpayers and for a much larger share of net investment income, this can be justified by the fact that these are intramarginal transactions. I return in section 6 to discuss this as well as the special tax rules that apply to the interest paid on owner-occupied house mortgages.

7 This analysis assumes that all borrowing is done by corporate businesses and all lending and portfolio equity investment is done by households. 
ers of equity capital. That would of course mean that the return to equity investors would increase relative to the return to the providers of debt. In practice, such a shift in relative returns is unlikely, since bondholders would then want to shift out of bonds and into equities, thus raising the interest rates on bonds and reducing the yield on equities. A sensible analysis must therefore recognize that eliminating the corporate tax would, with a fixed capital stock and therefore a fixed marginal product of capital, raise the returns on both debt and equity.

The relation between the interest rate and the equity return depends on the preferences of portfolio investors who hold debt and equity and on the preferences of firms that issue debt and equity capital. Rather than develop an explicit model of these preferences and the resulting market equilibrium, I consider two limiting cases. In the first case, the relation between debt and equity yields depends solely on the preferences of households. In effect, the households are willing to hold debt and equity if and only if they receive a fixed equity premium between the households' return on equity (net of the personal tax rate) ${ }^{8}$ and the corresponding rate of interest net of the personal tax rate. The alternative extreme assumption is that the gap between the equity yield and the rate of interest is determined solely by the preferences of firms. In this case, the firms supply relative quantities of debt and equity to keep a fixed difference between the cost to the firms of equity capital and debt capital, taking into account the fact that interest payments (but not payments to equity owners) are deductible against the corporate tax rate. This section examines the implications of assuming that household preferences determine the equity premium; while section 3 returns to examine the implications of assuming that the relative equity and debt yields depend on corporate preferences.

The basic reason that a shift to a consumption tax raises the rate of interest is that eliminating the corporate tax reduces the tax on corporate profits. Since interest payments are fully deductible in calculating the corporate profits tax liability, there is no direct effect of a change in the corporate tax on the rate of interest. Indeed, if the only source of finance for marginal investments were debt, changing or eliminating the corporate tax would have no effect at all on the rate of interest. But if incremental investments are financed by a mixture of debt and equity, the reduced tax on corporate profits would increase the return on equity. If the return on debt remained unchanged, the equity premium would widen inappropriately. The actual outcome is therefore an increase in both the equity yield and the pre-tax interest rates in a way that maintains the original

${ }^{8}$ This ignores the special tax treatment of capital gains; I return to that in section 4 . 
equity premium. In addition, elimination of the personal tax on investment income widens the net equity premium, requiring a further rise in the rate of interest to maintain the same net equity premium.

The magnitude of the rise in the interest rate in this simplified model is quite large. Consider the following realistic parameter values: a corporate tax rate of 35 percent, a personal tax rate on investment income of 30 percent, a real marginal product of capital of 10 percent, a debt-to-capital ratio of 40 percent, and an initial interest rate of 4 percent. With these assumptions, the analysis implies that shifting to a consumption tax (i.e., eliminating completely both the personal and the corporate income taxes) nearly doubles the long-run real interest rate, increasing it from 4 to 7.9 percent. 9

Since the shift to the consumption tax would eliminate the personal as well as the corporate income tax, the rate of interest net of the personal tax would rise even more. It can be shown that with the specific numerical values of the previous paragraph, the real net interest rate would rise from 4 percent to 10 percent, i.e., the interest rate would equal the real marginal product of capital. Since the interest rate would be raised to 7.9 percent by eliminating the corporate tax alone, less than half of the rise in the real net return from 4 percent to 10 percent is due to the direct effect of eliminating the personal tax on investment income. If however the corporate tax were retained at 35 percent while the personal tax on interest and dividends is eliminated, the real net return would rise from 4 percent to 7.2 percent.

Before considering alternative assumptions, including the alternative equity premium assumption and implication of a positive initial rate of inflation, I extend the analysis to consider how the likely response of savings to the increased net interest rate would change the equilibrium capital stock and therefore the pre-tax rate of interest.

\section{INTEREST-SENSITIVE SAVING AND THE EQUILIBRIUM INTEREST RATE}

Although the assumption of a fixed capital stock and therefore of a constant marginal product of capital may be a reasonable approximation in the short run, the very long-run equilibrium will reflect the effect of the consumption tax on the rate of saving and therefore on the equilibrium capital stock and the associated marginal product of capital. ${ }^{10}$ This

9 With those parameter values, the implied equity premium is 3.57 percent.

10 Even in the short run before the capital stock has changed, the anticipation of these long-run changes in capital intensity would affect long-term interest rates and asset prices. 
section discusses why the shift from an income tax to a consumption tax would raise the long-run equilibrium pre-tax rate of interest under the assumptions of section 1 even if savings respond positively to the higher net interest rate unless the saving response is much greater than suggested by previous research.

The link between the marginal product of capital and the saving rate depends on two things: (1) how changes in the saving rate change the capital-income ratio of the economy and (2) how changes in the capitalincome ratio alter the marginal product of capital. Consider first the link between the saving rate and the capital-income ratio. In a growing economy, the capital stock per dollar of national income remains constant if the gross saving rate is just enough to provide capital for the increased labor force and to replace the capital that is being lost through depreciation. This implies that a constant capital-income ratio is equal to the ratio of the gross saving rate to the sum of the depreciation rate and the rate of labor-force growth. Since labor-force growth and depreciation would not be altered by a change in tax policy, any tax-induced rise in the gross saving rate would raise the long-run capital-income ratio in the same proportion.

The second link, i.e., between the capital-income ratio and the marginal product of capital, depends on the production function for the economy as a whole. The standard assumption of a Cobb-Douglas production function implies that the share of investment income in national income remains constant as the capital-income ratio changes. Since investment income equals the marginal product of capital multiplied by the capital stock, the share of investment income in national income is the marginal product of capital multiplied by the ratio of capital to income. Since the ratio of capital to income equals the ratio of the gross saving rate to the fixed sum of depreciation and population growth, the marginal product of capital varies inversely with the saving rate. ${ }^{11}$

With the parameter values presented at the end of section 1 , this implies that the pre-tax rate of interest declines only if the shift from an income tax to a consumption tax causes the gross saving rate to rise by more than 60 percent. This would imply that the gross saving rate rises from 20 percent to 33 percent. To put this increase in perspective, note that the gross saving rate in the United States averaged 19 percent of GDP from 1970 to 1992, while the gross saving rate in Japan during those years averaged 32 percent.

11 In notation that will be obvious to economists, the Cobb-Douglas production function $y=a k^{\alpha}$ implies $f^{\prime}=\alpha a k^{\alpha-1}$. With the equilibrium growth condition $\sigma y=g k$, it follows that $f^{\prime}=\alpha g / \sigma$. 
Although a large enough increase in the return to saving might conceivably induce such an increase, the condition that the pre-tax rate of interest does not increase implies that the overall rise in the reward to saving is relatively small. Using the parameter assumptions introduced in the previous section implies that switching to a consumption tax would cause the real net return to savers to rise from 4.9 percent to at most 6.1 percent if the pre-tax rate of interest did not rise. A 60-percent rise in the saving rate in response to a 1.2-percentage-point increase in the rate of return is much greater than implied by previous research on the sensitivity of saving to the net rate of return. ${ }^{12}$ With a saving increase of less than 60 percent when the pre-tax interest rate is unchanged, it follows that the shift to a consumption tax would raise the rate of interest.

Even if the gross saving rate increased by a very substantial 30 percent (from 0.20 to 0.26 ), the pre-tax rate of interest would rise from an initial 4 percent to 5.5 percent.

\section{AN ALTERNATIVE RELATION BETWEEN DEBT AND EQUITY YIELDS}

The analysis of sections 1 and 2 assumed that the relation between the equity yield and the rate of interest is determined by the preferences of households alone. In order to bracket the outcome that would reflect the interaction of the preferences of investors and of firms, the current section discusses the implications of the extreme alternative assumption that the relation between the equity yield and the rate of interest is determined by the preferences of the firms alone.

The cost of equity capital to the firm is the pre-tax cost of equity (i.e., the firm gets no deduction for payments made to shareholders), while the cost of debt capital to the firm is the interest rate net of the deduction at the corporate rate. ${ }^{13}$ Thus, with a fixed capital-income ratio and therefore a fixed marginal product of capital (as in section 1), the alternative assumption about the long-run relation between debt and equity returns does not alter the conclusion that eliminating the corporate tax would raise the rate of interest and, in particular, that eliminating the corporate tax in the process of switching to a consumption tax would cause the rate of interest to increase from 4 to 6.1 percent. Although this is less than the

12 See among others Boskin (1978), Hall (1987), and the discussion in Feldstein (1995a).

13 The parameter values presented at the end of section $2 \mathrm{imply}$ that the equity premium as viewed by the firm is 6.5 percent; i.e., the firm is willing to pay 6.5 percent more on equity capital than its net-of-tax cost of debt funds. This of course implies the same net equity premium of 3.57 percent for the individual investor. 
increase to 7.9 percent if consumers' preferences determine the outcome, it is still a significant rise.

If the saving rate responds to a rise in the net rate of return, calculations similar to those discussed in section 3 imply that the pre-tax rate of interest would rise unless the gross saving rate increases by at least 27 percent. Although this is not as large as the increase required in the case examined in section 2, it is still quite large relative to the increased net return to savers.

More specifically, eliminating the corporate and personal taxes on investment income would cause the real net return to savers to rise from 4.9 to 7.9 percent even if the real pre-tax interest rate remained unchanged at 4 percent. This is substantially larger than the 1.2-percentage-point increase in the net return implied by the alternative model of capital market equilibrium in section 2. If this 3.0-percentage-point rise in the net rate of return were to raise the gross saving rate by 27 percent (e.g., from 20 percent to 25.4 percent), the shift to a consumption tax with this section's mode of capital-market equilibrium would lead to a lower equilibrium pre-tax rate of interest.

\section{INFLATION, CONSUMPTION TAXES, AND THE RATE OF INTEREST}

To permit a clearer exposition, the analysis until now has assumed that there is no inflation and that tax depreciation is equal to economic depreciation. This section presents numerical results for a more complete specification that incorporates a positive rate of inflation and a more realistic analysis of tax depreciation.

The interaction between inflation and tax rules is important because the personal and business income taxes are based on nominal interest income and expenses, on nominal capital gains, and on nominal depreciation. ${ }^{14}$ In this more realistic analysis, the nominal return that the firm can give to the providers of debt and equity capital (per unit of capital before personal taxes) is the sum of three components: the real marginal product of capital plus the rise in the nominal value of the capital stock minus the tax paid by the corporations. The corporate tax base is now the sum of four components: (1) the marginal product of capital, (2) the value of accelerated depreciation per unit of capital, (3) the reduced depreciation allowance caused by inflation, and (4) the deduction for the nominal interest payments.

14 See Feldstein (1983) for several papers on the interaction of inflation and tax rules. 
Because the individual provider of debt capital pays tax on the nominal rate of interest, the real net-of-tax rate of interest is the net-of-tax nominal interest rate minus the rate of inflation. The equity investor receives a total pre-tax nominal return per unit of equity capital that reflects the payout of real earnings plus the inflationary appreciation of the capital stock..$^{15}$ This appreciation is taxed only on a deferred basis and only if realized, while the remaining return to equity capital is subject to tax at the personal income tax rate.

Consider now the effect of going to a consumption tax in this more realistic context (and with the assumption of sections 1 and 2 that the equity premium is determined by the preferences of individual investors.) Inflation is important because inflation raises the effective tax rate at the corporate level; this occurs because the historic-cost method of calculating depreciation reduces the real present value of depreciation when there is inflation. Eliminating the corporate income tax therefore raises net-of-tax profits more when there is inflation.

In contrast, a positive rate of inflation makes the pre-tax nominal interest rate less sensitive to changes in the personal-income-tax rate. This effect of inflation occurs because inflation reduces the net yield on equities by introducing a tax on nominal capital gains. Market equilibrium therefore requires that the net yield on fixed-income securities also decline because of inflation. This effect could even theoretically imply that eliminating the taxation of personal interest income could lower the rate of interest.

Despite this theoretical ambiguity caused by the opposite effects of eliminating the corporate and personal income taxes, realistic numerical values indicate that switching to a consumption tax would cause a larger increase in the real pre-tax interest rate when there is inflation. In addition to the assumptions of section 1, let the rate of inflation be 4 percent. Although the effect of inflation on the real rate of interest is ambiguous in an economy with a complex set of non-neutral tax rules, the evidence suggests that these effects interact in practice in a way that keeps the real pre-tax rate of interest approximately unchanged when the rate of inflation changes. ${ }^{16}$ With the real rate of interest unchanged at 4 percent, the initial value of the nominal interest rate is 8 percent. Assume also that in the absence of inflation there is accelerated depreciation that is equivalent to adding 1 percent to the pre-tax rate of return and that the historiccost method of depreciation causes each percentage point of inflation to

15 This assumes that there are no retained earnings.

16 See e.g., Feldstein (1983) and Mishkin (1992). 
reduce net profits per unit of capital by 0.2 percent. ${ }^{17}$ Finally, I shall assume that each dollar of accrued capital gain only raises the present value of future taxes by one-fourth of the statutory personal tax rate, a reflection of the deferral, the stepped-up basis at death, and the lower statutory tax rate on capital gains than on other capital income.

These values imply that eliminating the personal income tax on investment income would have a smaller effect on the equilibrium interest rate than in the previous case: shifting from the current tax system to a consumption tax raises the real interest rate from 4 to 6.9 percent. ${ }^{18}$

Before considering the effect of an endogenous capital stock, consider the alternative capital market equilibrium in which the real cost of equity capital to the firm exceeds the real net cost of debt capital by a constant differential. In this case, shifting from the existing tax structure to a consumption tax would raise the real interest rate from 4 to 5.2 percent. Comparing this with the result with the alternative capital market equilibrium implies that, with a fixed capital stock, the rise in the real interest rate is from 4 percent to between 5.2 and 6.9 percent.

\section{INFLATION AND SAVING}

The results of section 4 can be extended to an economy in which the saving rate responds to the real return to savers (by combining the analyses of sections 2 and 4 and sections 3 and 4.)

The analysis of section 4 for the case in which the equity premium reflects individuals' preferences showed that shifting from the current tax rules to a consumption tax implies that the real interest rate would rise from 4 to 6.9 percent if the capital intensity is fixed (i.e., with no change in saving). To offset this and keep the interest rate from rising requires (with the parameter values used in the previous section) the gross saving rate to increase by 41 percent.

With a fixed nominal interest rate of 8 percent, shifting to a consumption tax would raise the real net rate of return by 2.4 percentage points, from 4.7 to 7.1 percent. If this rise in the net rate of return is enough to increase gross saving by 41 percent, the pre-tax interest rate would decline.

Finally, there is a similar analysis with the risk premium based on the

17 See Feldstein, Green, and Sheshinski (1978) for analytic discussions of the effect of inflation on the value of depreciation allowances. The number 0.2 used in the text is based on the calculation by Alan Auerbach presented in his appendix to that paper.

18 As an alternative to the assumption that inflation does not alter the real pre-tax interest rate, I have also considered the implication of keeping the equity premium unchanged at the value implied by zero inflation. With this assumption, shifting to a consumption tax implies that the real interest rate rises from 0.058 to 0.076 . 
firms' preferences. This is the case most favorable to the conclusion that shifting to a consumption tax would cause the pre-tax return to fall. In this case, the numerical values that we have been assuming imply that the real interest rate would rise from 4 to 5.2 percent if the saving rate is unchanged and would decline if the gross saving rate rises by at least 13 percent. With a 13-percent increase in gross saving, the shift to a consumption tax would leave the pre-tax interest rate unchanged but would cause the real net return to savers to rise from 4.7 to 8.8 percent. This combination is more plausible than the larger saving responses required under the alternative market equilibrium conditions and inflation assumptions discussed above.

\section{CONCLUDING COMMENTS}

The analysis in this paper has used very simple models of business borrowers and household portfolio investors. In reality there are several other types of borrowers and investors in quite different tax situations. The actual change in the interest rate will depend on their role in the overall capital market equilibrium.

There are five primary participants in the capital market other than the corporate borrowers and taxable portfolio investors that have been the focus of the current analysis: household mortgage borrowers; the federal government; foreign borrowers and investors; tax-exempt portfolio investors; and state and local government borrowers. Although incorporating these in a formal analysis lies beyond the scope of the current paper, some brief comments on their likely effect on the equilibrium interest rate can be made.

Household mortgage borrowing is now tax-deductible, increasing the demand for mortgage credit and diverting capital from the business sector to owner-occupied housing. Eliminating the income tax would remove this incentive to overinvest in such housing. With more of the capital stock in business plant and equipment, the marginal product of capital in that sector would decline, leading to a lower interest rate. ${ }^{19}$

The federal government is an intramarginal borrower that is clearly not directly sensitive to changes in tax rates and that can be assumed to be insensitive to changes in interest rates. The presence of government bonds should therefore not alter the basic effect of the tax change discussed in this paper.

19 Feldstein (1995b) showed that with plausible parameters to describe housing demand the interest rate would still rise unless a 2.4-percent rise in the real interest rate is sufficient to induce an increase in saving equal to 2.2 percent of GDP. 
Foreign borrowers and investors who are not subject to U.S. tax rules would dampen the magnitude of any interest-rate change. If capital moved among national capital markets to equalize real rates of return, there could be no response of U.S. real interest rates to the change in tax rules. Instead of a rise in the rate of interest, capital would flow into the United States, depressing the pre-tax marginal product of capital until the equilibrium U.S. interest rate was at the world level. In practice, capital movements are more limited, and an increased demand for corporate capital in the United States would be expected to change the level of U.S. interest rates. ${ }^{20}$

A large fraction of bonds are held by pension funds and other taxexempt portfolio investors. For them, the shift to a consumption tax would involve no change in tax rates. Even if all portfolio investors were tax-exempt, eliminating the corporate tax would lead to a rise in the rate of interest. The return to tax-exempt investors would therefore rise even though they are not directly affected by the change in tax rules.

State and local government bonds are currently untaxed. Under a consumption tax they would lose their favored status, since no interest income would be taxed. Interest rates on these obligations would therefore rise relative to other interest rates. To the extent that state and local government borrowing is interest-sensitive, this would reduce the demand for credit and therefore reduce the overall rise in interest rates.

Although it would be useful to have a formal analysis with this broader class of borrowers and lenders, it appears from this informal discussion that doing so would not alter the basic conclusion that shifting to a consumption tax is likely to raise pre-tax interest rates.

\section{APPENDIX A: THE EQUIVALENCE OF ALTERNATIVE CONSUMPTION TAXES}

Two seemingly different types of individual consumption taxes are now being discussed. ${ }^{21}$ The consumed-income tax permits a deduction for all net saving but continues to include investment income in the individual's tax base..$^{22}$ The alternative consumption-type tax has no deduction

${ }^{20}$ On the limited net movement of capital among national capital markets, see the substantial literature cited in Mussa and Goldstein (1993) and Feldstein (1994). See also Hartman (1979) for a discussion of tax-induced intemational capital arbitrage.

${ }^{21}$ I use the term "individual consumption tax" to refer to taxes based on returns filed by individuals. The other consumption taxes, collected from producers or sellers, are the VAT and the national retail sales tax.

22 A proposal of this type has been made by Senators Pete Domenici and Sam Nunn; see "USA Tax System" (Nunn and Domenici, 1995). An earlier and somewhat different form of 
for saving but excludes investment income from the tax base. ${ }^{23}$ Although these appear to be conceptually quite different, once a transition phase is completed they are exactly equivalent in the sense that they define the same lifetime budget constraint for each individual. ${ }^{24}$

To show this equivalence of the two types of taxes, I will look first at a consumed-income tax under which the individual deducts net saving in calculating the tax base. Consider how such a tax works in a simple lifecycle model in which the individual earns a fixed amount in the first period of his life and retires in the second period. The individual earns wage income $W$ in the first period and chooses to save an amount $S$. If the tax rate is $t$, the tax paid at that time is $t(W-S)$ and first-period consumption is therefore $C_{1}=(1-t)(W-S)$. The savings earn a rate of return of $R$ and therefore grow to $(1+R) S$ by the second period. In that second period the individual pays tax on the dissaved original principle $S$ as well as on the investment income $R S$. Second-period consumption is therefore $C_{2}=(1-t)(1+R) S$. Simple algebra implies that $C_{1}=(1-t)$ $(W-S)$ can be rewritten as $(1-t) S=(1-t) W-C_{1}$. The relation between consumption in the second period and consumption in the first periodi.e., the individual's lifetime budget constraint with a consumed income tax-can therefore be written

$$
C_{2}=(1+R)\left[(1-t) W-C_{1}\right]
$$

Consider now a tax system in which there is no special treatment of savings per se but in which the interest and dividends earned on savings are untaxed. The first-period tax is therefore $t W$, and the savings are $(1-t) W-C_{1}$. Since there is no tax on the return to that saving, the second-period consumption is again given by

$$
C_{2}=(1+R)\left[(1-t) W-C_{1}\right] .
$$

a consumed-income tax is discussed in U.S. Treasury (1977) and in Bradford (1986). The idea of such a consumed-income tax among economists goes back at least to Kaldor (1955). A pure value-added tax or national retail sales tax would also have the effect of excluding net saving; they are discussed later in this appendix.

23 Congressman Richard Armey has recently proposed such a tax based on the collection mechanism described in Hall and Rabushka (1995). The Armey tax collects a fixed fraction of wages and salaries above a deductible amount from individuals through withholding or subsequent direct payments. The same fraction of all nonwage compensation paid by firms (i.e., firing benefits, deferred compensation, etc.) is collected directly from the firms.

24 Transition rules in the consumed-income tax that avoid taxing the dissaving of amounts accumulated under the existing income-tax system could make the two systems similar from the start. The long-run equivalence assumes that the two systems have equivalent untaxed excluded amounts and that the tax rate in each system remains unchanged during the individual's life. 
This establishes that each individual's lifetime budget constraint is exactly the same under both taxes. The individual will therefore choose the same path of consumption. Since the pre-tax income and consumption are the same, the value of the taxes is also the same.

The intuition for the equivalence is clear: the savings deduction in the consumed-income tax is really only a postponement of tax, since the dissaving must be included in retirement income and the advantage of the postponement is offset (relative to the interest exclusion rule) by taxing the interest on the saving.

A third type of consumption tax, a consumption value-added tax or national retail sales tax, is really a variant on the first of the two consumption taxes described above ${ }^{25}$ and therefore equivalent also to the second type of consumption tax. With such a VAT, individuals who have real consumption of $C_{1}$ spend $(1+v) C_{1}$, where $v$ is the rate of value-added tax or retail sales tax. If the individuals earn $W$, their saving is given by $S=$ $W-(1+v) C_{1}$. The saving provides funds available for spending on second-period consumption equal to $(1+R) S$. But since that consumption in the second period is also subject to a value-added tax at rate $v$, the actual second-period consumption $C_{2}$ satisfies $(1+v) C_{2}=(1+R) S$, or $(1+v) C_{2}=(1+R)\left[W-(1+v) C_{1}\right]$. Dividing both sides by $1+v$ yields

$$
C_{2}=(1+R)\left[(1+v)^{-1} W-C_{1}\right] .
$$

If the VAT rate $v$ is selected so that $(1+v)^{-1}=1-t$, equation (A.3) defines the same lifetime budget constraint as equations (A.1) and (A.2). More generally, adding a value-added tax or a national retail sales tax to the direct personal consumption tax does not alter the lifetime budget constraint.

The text of the paper therefore refers to the effect of a "consumption tax" without distinguishing between the different types of consumption taxes.

\section{APPENDIX B: THE EFFECT OF SHIFTING TO A CONSUMPTION TAX WITH A FIXED CAPITAL STOCK}

This appendix provides a formal statement of the analysis described in section 1 of the text. It shows how the equilibrium pre-tax rate of interest and the net rate of return to savers would respond to changes in the personal tax rate and the corporate tax rate in an economy with a fixed

25 This simplifies by assuming that all consumption is included in the VAT base. In practice, most countries with value-added taxes exclude certain types of consumption (e.g., medical care, education, some types of food, housing) or tax them at lower rates. See Feldstein and Krugman (1990) for a discussion of the implication of this in an open economy. 
stock of capital and a zero rate of inflation. The fixed capital stock in this one-sector economy implies that the corporate borrowers earn a fixed pre-tax marginal product of capital, $f^{\prime} .{ }^{26} \mathrm{~A}$ fraction $b$ of capital is debt on which the firm pays an interest rate of $i$. The equity investors receive a return of $e$ per dollar of equity capital. If the corporate tax rate is $\tau$, the firm's budget constraint is given by

$$
(1-\tau) f^{\prime}=(1-\tau) b i+(1-b) e .
$$

This reflects the fact that the interest payments are deductible in calculating taxable profits while the return to equity investors is not. ${ }^{27}$

If the representative individual has marginal tax rate $\theta$, that individual's net return is ${ }^{28}$

$$
r_{\mathrm{N}}=(1-\theta)[b i+(1-b) e]
$$

The relation between the interest rate and the equity return depends on the preferences of portfolio investors who hold debt and equity and on the preferences of firms that issue debt and equity capital. Rather than develop an explicit model of these preferences and the resulting market equilibrium, I consider two limiting cases. In the first case, the relation between debt and equity yields depends solely on the preferences of households. In effect, the relative demand for debt and for equity are infinitely elastic at a fixed equity premium, $\phi$, between the households' net-of-tax return on equity and the corresponding net-of-tax rate of interest:

$$
(1-\theta) e=(1-\theta) i+\phi
$$

The alternative extreme assumption is that the gap between the equity. yield and the rate of interest is determined solely by the preferences of firms. In this case, the relative supplies of debt and equity are infinitely elastic at a fixed equity premium, $\psi$, between the firms' net-of-tax cost of equity and debt capital:

$$
e=(1-\tau) i+\psi
$$

26 This analysis assumes that all borrowing is done by corporate businesses and all lending and portfolio equity investment is done by households.

27 Assuming that the marginal product of capital is taxed at the same statutory rate that applies to interest deductions implicitly assumes that economic depreciation is allowed for tax purposes. This is discussed further in the text of the paper.

${ }^{28}$ This ignores the special tax treatment of capital gains. This is discussed further in the text of the paper. 
Note that equations (B.3a) and B.3b) differ not only in the tax that is relevant but also in the fact that both equity and debt are taxed to portfolio investors while the corporate tax deduction applies only to the interest payments.

This appendix examines the implications of assuming that household preferences determine the equity premium [equation (B.3a)], whereas section 3 of the main text (and the corresponding section of the working paper) returns to examine the implications of assuming that the relative equity and debt yields depend on corporate preferences [equation (B.3b)].

Combining (B.1) and (B.3a) and differentiating with respect to $\tau, \theta$, and $i$ yields

$$
-f^{\prime} d \tau=[(1-\tau) b+(1-b)] d i-b i d \tau+(1-b) \phi(1-\theta)^{-2} d \theta
$$

Therefore

$$
\frac{d i}{d \tau}=-\frac{f^{\prime}-b i}{1-\tau b}
$$

and

$$
\frac{d i}{d \theta}=-\frac{(1-b) \phi(1-\theta)^{-2}}{1-\tau b}
$$

Since $f^{\prime}-b i>0$ and $1-\tau b>0$, it follows that $d i / d \tau<0$, so that a reduction of the corporate tax rate causes the pre-tax interest rate to rise. Similarly, $b$ $<1$ and $\theta<1$ imply $d i / d \theta<0$, so that a reduction of the personal tax on investment income also raises the pre-tax interest rate. Since the shift to a consumption tax would eliminate the corporate $\operatorname{tax}(d \tau=-\tau)$ and the personal tax on investment income $(d \theta=-\theta)$, it would raise the rate of interest by $d i=\left[\left(f^{\prime}-b i\right) \tau+(1-b) \phi(1-\theta)^{-2} \theta\right] /(1-\tau b)$.

To understand why this shift to a consumption tax raises the rate of interest, note first that reducing or eliminating the corporate tax reduces the tax on corporate profits $\left(f^{\prime}-b i\right)$ directly. Since interest payments are fully deductible, there is no direct effect of a change in $\tau$ on $i .{ }^{29}$ But if the reduced tax on corporate profits were allowed to increase the return on equity while the return on debt remained unchanged, the equity premium would widen inappropriately. The actual outcome is therefore an increase in both $e$ and $i$ in a way that maintains the original equity becomes $(1-\tau) f^{\prime}=(1-\tau) i$ and a change in $\tau$ has no effect on $i$. 
premium. In addition, the elimination of the personal tax on investment income widens the net equity premium, requiring a further rise in the rate of interest to maintain the same net equity premium.

The large magnitude of the rise in the interest rate in this simplified model is discussed in section 1 of the text of the paper.

\section{REFERENCES}

Boskin, Michael (1978). "Taxation, Saving and the Rate of Interest. Journal of Political Economy, V86(2) Part II ppS3-S28.

Bradford, David (1986). Untangling the Income Tax. Cambridge: Harvard University Press.

(1995). "Consumption Taxes: Some Fundamental Transition Issues." October. NBER Working Paper no. 5290.

Feldstein, Martin (1983). Inflation, Tax Rules and Capital Formation. Chicago: University of Chicago Press.

(1994). "Tax Policy and International Capital Flows. The 1994 Bernhard Harms Lecture." Weltwirtschaftsliches Archiv, 1994 (no. 4):675-697.

- (1995a). "Fiscal Policies, Capital Formation and Capitalism. The 1994 Joseph Schumpeter Lecture to the European Economic Association." European Economic Review 39:399-420.

(1995b). "The Effect of a Consumption Tax on the Rate of Interest." NBER Working Paper no. 5397.

- Jerry Green, and Eytan Sheshinski (1978). "Inflation and Taxes in a Growing Economy with Debt and Equity Finance." Journal of Political Economy, Part 2 (April):S53-S70.

- and Paul Krugman (1990). "International Trade Effects of Value-Added Taxation." In Taxation in the Global Economy, Assaf Razin and Joel B. Slemrod (eds.). Chicago: University of Chicago Press.

Hall, Robert (1987). "Real Interest and Consumption." Journal of Political Economy. (1996). "The Effect of Tax Reform on Prices and Asset Values." In Tax Policy and The Economy-1995, J. Poterba (ed.). Cambridge, MA: MIT Press. Press.

Hartman, David (1979). "Taxation and the Effects of Inflation and the Effects of Inflation on the Real Capital Stock in an Open Economy." International Economic Review 20(2, June):417-425.

Kaldor (1955). "An Expenditure Tax." London: Allen and Unwin.

Mishkin, Frederic (1992). "Is the Fisher Effect for Real?" Journal of Monetary Economics 30:195-215.

Mussa, Michael, and M. Goldstein (1993). "The Integration of World Capital Markets." In Changing Capital Markets: Implications for Monetary Policy. Kansas City, MO: Federal Reserve Bank of Kansas City.

Nunn, Samuel, and Peter Domenici (1995). "USA Tax System." Tax Notes, 65(11, March 10).

Toder, Eric (1995). "Comments on Proposals for Fundamental Tax Reforms." Tax Notes (March 27): 2003-2015.

U.S. Treasury (1977). Blueprints for Basic Tax Reform. Washington, DC: US Government Printing Office. 



\title{
FUNDAMENTAL TAX REFORM AND CORPORATE FINANCIAL POLICY
}

\section{William M. Gentry and R. Glenn Hubbard}

\author{
Columbia University and NBER
}

\section{EXECUTIVE SUMMARY}

The effects of tax reform on corporate financial decisions help determine whether reform will increase capital formation and simplify the tax system. This paper describes the effects of fundamental tax reform on corporate tax planning and summarizes economists' knowledge of the magnitude of these effects. We analyze both income tax reform, consisting of integrating the corporate and personal income taxes, and moving to a broad-based consumption tax. As prototypes of reform, we use the U.S. Treasury's comprehensive business income tax proposal for income tax reform and the flat tax for consumption tax reform. The critical difference between these reforms is that the consumption tax gives firms immediate deductions for capital outlays instead of the depreciation allowances of the income tax.

Tax reform can affect business organizational form, capital structure, and timing decisions. Our major theme is that the two types of reform will have similar effects on business financial decisions because they both integrate corporate and personal income taxes. Both reforms eliminate the tax differentials between corporate and noncorporate businesses and between debt and equity financing. Since both reforms eliminate investor-

We are grateful to David Bradford, Robert Hall, and Laura Kalambokidis, participants in the NBER Conference on Asset Price and Transition Effects of Consumption Tax Reform, and seminar participants at Columbia, Georgetown Law School, Tufts, the Federal Reserve Bank of Philadelphia, and the American Enterprise Institute for helpful comments and suggestions, and to James Combs for excellent research assistance. 
level taxes on financial assets, they reduce the effects of taxes on timing decisions associated with financial assets, such as the timing of corporate dividends. Assumptions about how taxes affect these various financial decisions have important implications for the incidence of the corporate tax. These reforms also greatly alter the current incentives for taxmotivated financial planning.

\section{INTRODUCTION}

Proponents of fundamental tax reform in the United States claim that tax reform would increase saving and investment (see, e.g., the analysis in Auerbach, 1996) and create a simpler tax system (see, e.g., the analysis in Slemrod and Bakija, 1996). Both of these claims depend on how reform would change the tax treatment of business organization and financing decisions. These decisions help determine the allocative and efficiency consequences of capital taxation, an important input for analyzing the effects of tax reform on saving and investment. For example, if borrowing is the marginal source of funds, Stiglitz (1973) concludes that the corporate income tax is a nondistortionary tax on economic profit that does not change the rate of return to capital; in contrast, general equilibrium models of the corporate income tax, starting with Harberger (1962), typically assume equity-financed investment and find that the corporate income tax lowers the rate of return to capital. Regarding tax simplification, much of the current tax system's complexity arises from taxing capital income; hence whether reform can simplify the tax system depends on its effects on the tax incentives for financial planning. In this paper, we describe the major effect of fundamental tax reform on corporate tax planning and summarize economists' knowledge of the magnitude of these different effects.

"Fundamental tax reform" is a broad term that encompasses a wide range of policies, including income-tax reforms and replacing the current tax system with a broad-based consumption tax. Despite this range of policies, possible reforms have several common features. First, a common goal of tax reforms is to reduce the disparity in tax rates across different types of real assets and across different financial contracts. Second, fundamental tax reforms of both the income and consumption variety typically call for a broader tax base with lower marginal tax rates. For income- tax reform, our definition of fundamental tax reform includes proposals to integrate the personal and corporate tax systems and move toward a more consistent definition of income across types of assets. Moving to a consumption tax can be thought of as taking such an income-tax reform one step further-the consumption tax would replace 
the system of depreciation allowances under the integrated income tax with immediate deductions for capital outlays of businesses. A major theme of our analysis is that since the two reforms share this first step, many of their effects on corporate financing decisions are similar.

We identify two major areas of policy concern. First, available evidence on the importance of financing and organizational distortions suggest efficiency gains from fundamental income- or consumption-tax reform. Second, fundamental tax reform could greatly alter the taxplanning landscape, which would impact the complex financial transactions (e.g., derivatives and swap contracts) that firms use to lower their tax payments under current tax rules.

This paper proceeds as follows. Section 2 describes tax planning under the current tax system. Section 3 briefly outlines prototypes for tax reform and their treatment of the business sector and financial assets. Sections 4-6 evaluate distortions of organizational form, capital structure, and timing, respectively. Section 7 links assumptions about financing distortions with analyses of the incidence of the corporate tax. In section 8 , we evaluate likely tax planning opportunities in the aftermath of tax reform. Section 9 concludes.

\section{TAX PLANNING UNDER THE CURRENT TAX SYSTEM}

The current U.S. tax system is a hybrid of income- and consumption-tax rules (see, e.g., the review in Engen and Gale, 1996). The reasons behind the hybrid tax system include both administrative issues (e.g., difficulties in measuring income accruing as unrealized capital gains or as consumption flows from consumer-owned durables) and policy choices (e.g., special tax provisions for retirement saving). As part of this hybrid, the United States has a classical corporate income tax. This system taxes corporate income twice, once at the entity level and again at the investor level.

The classical corporate tax and the hybrid of consumption-tax and income-tax rules create incentives for firms to minimize their tax liabilities through financial planning. Specifically, these incentives include discouraging incorporation, encouraging borrowing (since the interest payments on debt-financed corporate investment are tax-deductible), and altering the timing of transactions (including the payment of dividends and the sale of assets). In sections $4-6$, we provide more details on these incentives and how fundamental tax reform would affect them.

While firms sometimes respond to tax incentives by changing their 
financial plans, firms also creatively design contracts to get the tax benefits of a decision without incurring all of the associated non-tax costs. For example, firms write contracts that blur the non-tax distinction between debt and equity but qualify for interest deductions for tax purposes. Such financial "engineering" challenges the tax authorities to distinguish between different contracts. This cycle of financial innovation and regulation increases the complexity of the tax system. Furthermore, if firms differ in their access to these techniques, then this planning creates unintended distortions across firms. In the sections on organizational form, capital structure, and timing, we illustrate how the tax system encourages financial innovation.

Before describing the impact of potential tax reforms on tax planning, we review how the current system creates tax planning opportunities. The returns to tax planning depend both on the level of tax rates and on the dispersion of tax rates across investors or assets. Higher tax rates increase the returns to arranging financial contracts to minimize taxable income. Tax rate differentials-across investors and across different types of income-play a crucial role in tax planning. The simplest tax rate differentials occur across investors. For example, with progressive taxation, marginal income-tax rates rise with income. In addition, taxable investors and tax-exempt investors, such as pension funds and notfor-profit organizations, face different tax rates. These differentials often reflect policy decisions that tax rates should vary depending on the ownership of income. Tax rate differentials across investors create incentives for investors with positive income trying to be classified as having a lower tax rate and investors with negative income trying to be classified as having a higher tax rate. For example, parents (corporations) with high marginal tax rates may try to shift income to their children (unconsolidated subsidiaries or pension funds) who face a lower marginal tax rate.

Stronger tax incentives occur when these tax rate differentials across investors are combined with tax differences across types of income or assets. The tax system has a myriad of distinctions among types of income and assets. Income can either be ordinary (e.g., wages, interest, or dividends) or capital (e.g., capital gains). Some investors face lower tax rates on capital gains than ordinary income. The timing of tax payments may also differ because some capital income is taxed on realization rather than accrual. Examples of how tax rules vary across assets include: depreciation schedules for cost recovery, rules to differentiate equity from debt, and rules applying to original issue debt to determine the accrual of interest income and deductions. These tax rules often rely inherently on arbitrary judgments. The rules for financial transactions 
are particularly difficult to design because a set of cash flows can be produced by many different financial arrangements. Unless all of these arrangements yield the same tax result, then taxpayers can choose the financial arrangement that minimizes their tax burdens.

Combining the tax rate differences across assets and investors creates clientele-based tax planning opportunities and, in some cases, the possibility of tax arbitrage. Investors with high tax rates are the natural clientele for lightly-taxed forms of income (e.g., high-tax-rate investors own municipal bonds) and investors with low tax rates tend towards highlytaxed assets (e.g., pension funds own corporate bonds). In its extreme form, tax planning leads to tax arbitrage-investments in which firms have a zero net position but earn income from the differential taxation of the components of the transaction.

Financial-market innovation has facilitated more advanced forms of tax planning. ${ }^{1}$ The flexibility inherent in financial assets simplifies splitting the returns on real assets to construct tax-motivated clienteles. Derivative securities and other complex transactions complicate defining ownership of an asset. For example, the risk involved in owning a share of stock can be undone by either selling the share, short-selling the share, or writing an appropriate set of options on the share; however, these three methods of disposing of risk are taxed differently. ${ }^{2}$ These differences in the taxation of economically similar transactions create arbitrage opportunities. Because the principal role of financial markets is to make financial claims liquid and fungible, it is inherently difficult to measure consistently the outcomes of these different transactions (see, e.g., Weisbach, 1995). For physical assets, however, it is relatively easy to assign ownership of the asset to an entity and measure the benefits and costs of ownership. ${ }^{3}$ Whether tax reform can successfully reduce the

1 While the economics and finance literature has long recognized the role of complex financial instruments in tax avoidance, the details of particular transactions are much more developed in the tax-law literature. Recent examples from the legal literature on the general issue of taxes and financial innovation include Kleinbard (1991), Shuldiner (1992), Warren (1993), Strnad (1994), and Weisbach (1995).

2 We are assuming that investors' portfolio choices are primarily motivated by risk and return considerations rather than the other benefits (or burdens) of ownership, such as voting and liability issues. Paul (1996) discusses the distinction between holding (versus disposing) of an asset for tax purposes and hedging risk as a substitute for disposing of the asset.

${ }^{3}$ While it is easier to assign ownership to the returns to physical assets than the returns to financial assets, some scope remains for tax planning with physical assets. Leases provide opportunities to separate the physical use of an asset from its ownership for tax purposes. However, as discussed below, the incentives for this tax planning are linked to disparities in marginal tax rates that tax reform would reduce. 
incentives for tax planning depends on whether it can decrease the tax rate differentials across investors and assets and lessen the scope for taxmotivated financial innovation.

\section{PROTOTYPES FOR FUNDAMENTAL TAX REFORM}

Proposals for fundamental tax reform typically suggest moving to either a more pure income tax or a more pure consumption tax. Although these two proposals appear to be on opposite ends of a spectrum, the purer income tax and the purer consumption tax may affect corporate financing decisions in similar ways. Moving to a purer tax system of either type would reduce tax-planning opportunities because tax-minimizing strategies often involve combining transactions with different tax treatments (i.e., part of the transaction receives pure income-tax treatment, while another part receives consumption-tax treatment) or by taking advantages of disparities in tax rates across investors. Thus either reform reduces the tax rate differentials discussed in the previous section.

In the next subsection, we describe a prototype of income-tax reform. We proceed to show how this income tax could be converted into a consumption tax and argue that this conversion would not have major implications for corporate finance issues. We conclude the section with an outline of how we define fundamental tax reform for the remainder of the paper.

\subsection{Broad-Based Income-Tax Reform}

For corporate financing decisions, the critical element of fundamental reform of the income tax is the integration of the corporate and the personal income-tax systems. In theory, integrating the systems would eliminate two distortions from the current tax system. First, integration would eliminate the distinction between corporate and noncorporate businesses by abolishing the double taxation of corporate income. Second, this reform would remove the differential taxation of debt and equity financing. Whether the actual tax reform process would deliver these benefits depends on the details of the new tax system.

The U.S. Treasury Department's recent study of corporate tax integration (see U.S. Department of the Treasury, 1992) presents several alternative approaches to integrating the individual and corporate tax systems. Rather than repeat this discussion of the various proposals, we outline a stylized version of one proposal, the comprehensive business income tax (CBIT). The goal of CBIT is to tax business income once. CBIT is a business-level tax on the return to capital of businesses. Broadly speaking, the business-level tax base under CBIT is revenue from the sale of 
goods or real assets less wages, material costs, and depreciation allowances for capital investments. To conform to standard income accounting principles, the CBIT base uses depreciation allowances that follow as closely as possible economic depreciation. Because CBIT includes a tax on capital income, it runs afoul of the standard income-tax accounting problem of adjusting for inflation. To tax real, rather than nominal, capital income, the cost recovery system (depreciation allowances) must be indexed for inflation. CBIT does not distinguish whether investment is financed by debt or equity. That is, in contrast with the current tax system, CBIT would not allow businesses to deduct interest payments from their tax base. ${ }^{4}$ Because CBIT taxes business income at the entity level, there is no need for investor-level taxes on capital gains, interest, or dividends received. 5

CBIT can be thought of as the capital income tax component of a broad-based income tax that collects taxes from labor income through a household-level wage tax. We assume, for simplicity, that the marginal tax rate in CBIT is the same as the marginal wage tax rate. With this assumption, capital and labor income face the same tax rate. If the wage tax rate differs from the CBIT rate, then labor and capital income face different tax rates; however, capital income from different types of assets faces a common tax rate regardless of whether it is financed by debt or by equity. ${ }^{6}$

\subsection{Converting the Income Tax into a Consumption Tax}

Converting CBIT into a consumption tax turns out to be quite straightforward. Instead of measuring business income through depreciation allowances, a consumption-tax version of CBIT would allow businesses a

4 As with a consumption tax, this raises questions about how to tax financial intermediaries. For suggestions, see U.S. Department of the Treasury (1992, Chapter 5) and Bradford (1996).

5 Moving beyond the business sector, an important distinction between a pure income tax (sometimes referred to as a "Haig-Simons" income tax) and the combination of CBIT and a wage tax is that CBIT does not tax capital income earned outside of business entities. Owner-occupied housing is the primary form of capital outside the reach of CBIT. While this distinction is important for analyzing the efficiency of tax reform proposals (e.g., the allocation of capital between housing and business uses) and the distribution of tax payments, it is less clear that this omission from the tax base greatly affects the corporate finance issues surrounding tax reform.

6 If the household and business tax rates differ, then tax planning opportunities arise from recharacterizing income as wage or capital income. This form of tax planning is especially relevant for closely held businesses that have more leeway in substituting a lightly taxed form of income for a more heavily taxed form of income. This type of tax planning is probably less relevant for publicly held corporations; however, it could create some forms of tax arbitrage for financial intermediaries. 
deduction for capital investments when assets are purchased. This adjustment converts the combination of CBIT and a wage tax into the flat tax proposed by Hall and Rabushka $(1983,1995)$. We use the flat tax as the model of the consumption tax for the purposes of this paper. ${ }^{7}$ Our focus on expensing as the central difference between CBIT and the flat tax reflects our emphasis on the effects of tax reform on business finance. The flat tax has an added advantage of mitigating the distortions of capital allocation between the business and housing sectors. In the aggregate, the tax base is a measure of consumption because sales between businesses induce offsetting inclusions and deductions for the seller and buyer: the seller's tax base increases by the purchase price, but the buyer's tax base decreases by the purchase price. If the buyer and seller face the same tax rate, then the transaction creates no revenue for the government. For business sales to households, the aggregate tax base increases by the value of the sale.

Having described CBIT and the flat tax in this way, we can see that the flat tax does not exempt all of what is commonly called "capital income" from taxation (see also Gentry and Hubbard, 1997a). Under the business cash-flow tax component of the flat tax, the present value of depreciation allowances for one dollar of current investment is one dollar, while the present value is less than one dollar under the income tax. For a risk-free investment project, the tax savings from depreciation allowances represent risk-free flows, ${ }^{8}$ which the firm would discount at the risk-free rate of interest. For a marginal investment (in which the expected rate of return just equals the discount rate), the up-front subsidy to investment provided by expensing equals the expected future tax payments. It is in this sense that the "return to capital" is not taxed under a cash-flow tax or a consumption tax. ${ }^{9}$

What about inframarginal investments? That is, in addition to risk-free projects, suppose that certain entrepreneurs have access to investments with inframarginal returns (associated with rents to ideas, managerial skill, or market power). In this case, what is taxed is rates of cash flow in

${ }^{7}$ Related issues arise in the discussion of consequences of other tax reform proposals. We describe other recent proposals in Gentry and Hubbard (1997a); see also Slemrod and Bakija (1996).

${ }^{8}$ Here we are abstracting from tax-loss asymmetries.

${ }^{9}$ Life-cycle simulation models used to evaluate tax reforms follow this intuition and generally assume one risk-free return on accumulated savings (see, e.g., Auerbach and Kotlikoff, 1987; Hubbard and Judd, 1987; Hubbard, Skinner, and Zeldes, 1995; and Engen and Gale, 1996). In such models, the shift from an income tax to a consumption tax is equivalent to forgiving the taxation of capital income from new saving and imposing a onetime tax on existing saving used to finance consumption. 
excess of the firm's discount rate for depreciation allowances. Cash flows representing inframarginal returns are taxed equivalently under the broad-based income tax and the cash-flow tax (or consumption tax). As long as the scale of inframarginal projects is limited (and entrepreneurs' project selection is optimal), the tax saving from expensing should be invested in another risk-free asset. Hence for inframarginal projects only the return representing the risk-free rate is untaxed under the cash-flow tax or consumption tax.

What about risky investments? First, risky investments generate ex post high or low returns. The component of capital income that represents luck after a risky investment has been made can be treated like the inframarginal return in the foregoing example of the income tax and the cash flow tax. Second, risky investments have a higher $e x$ ante required rate of return than risk-free investments, reflecting a risk premium to compensate savers for bearing risk. Whether either tax system levies a tax on the risk premium depends on how one defines a "tax." If a tax is defined as an increase in expected government revenue, then both the income tax and the cash-flow tax include the risk premium. If, in contrast, a tax is an increase in the discounted present value of government revenue, then neither tax system includes the risk premium. In either case, the central point is that the stylized income tax and consumption tax treat the return to risktaking similarly.

To summarize, what is often called the return to capital can be thought of as the sum of the risk-free return (opportunity cost), inframarginal returns (economic profits), and returns to risktaking (payment for bearing risk and luck). In contrast to the base of the consumption tax, the income tax includes the opportunity cost of capital, which equals the rate of return on a marginal riskless project.

\subsection{Working Definition of Tax Reform}

For the remainder of the paper, we use the term "fundamental tax reform" to represent tax proposals with the following characteristics:

1. It is a combination of a business-level tax (with either cash flow or business income as the base) and a household wage tax.

2. For an income-tax version of reform, we assume that depreciation allowances are as close to economic depreciation as possible; for a consumption-tax version of reform, businesses will deduct capital expenditures.

3. The business-level tax does not distinguish between debt and equity financing.

4. In order to minimize the differences in marginal tax rates across busi- 
ness entities and investments, firms carry net operating losses forward with interest. ${ }^{10}$

5. There are lower marginal tax rates with a single marginal tax rate across business entities and households; the household tax can have a personal or family exemption.

Because fundamental tax reform implies either income-tax reform or moving to a consumption tax, we will distinguish between effects on corporate finance issues that do not depend on the choice of tax reforms from effects that differ between the two reform proposals.

\section{ORGANIZATIONAL-FORM DISTORTIONS}

Traditional arguments for eliminating differential capital taxation have focused on the distortions of business organizational form ${ }^{11}$ arising from a classical corporate income tax. By taxing corporate equity income twice, the classical corporate tax system discourages equity-financed investment by corporations. In addition, the corporate sector must earn a higher pre-tax rate of profit to prevent capital from flowing to the noncorporate sector. The tax distorts the allocation of resources by discouraging the use of the corporate form even when incorporation would provide non-tax benefits-such as limited liability for the owners, centralized management, free transferability of interests, and continuity. Since Harberger's (1962) seminal research, more sophisticated models have been constructed to determine the costs of the economic distortions caused by the corporate income tax (see the studies reviewed in Shoven and Whalley, 1992, and U.S. Department of the Treasury, 1992). For

${ }^{10}$ The actual CBIT and flat-tax proposals do not include interest for tax-loss carryforwards. These proposals would probably maintain something like the current tax rules that allow limited carrybacks and carryforwards of current tax losses without an adjustment for the time value of money. With such rules, effective tax rates can still vary across firms even when all firms face the same statutory marginal tax rate. Hence these rules motivate several tax planning strategies, including leasing and some forms of corporate reorganization. These tax planning incentives would continue under tax reforms that retain such loss offset rules.

11 We discuss tax-induced distortions in business organizations in Gentry and Hubbard (1997b). In addition, because of our emphasis on corporate finance, we abstract from a more general discussion of intersectoral and interasset distortions caused by the current system of differential taxation of business capital income (see, e.g., Gravelle, 1981; Fullerton and Henderson, 1987; and Auerbach, 1989). For the most part, removing such distortions can be accomplished by fundamental income-tax reform in the form of CBIT (or the spirit of the Tax Reform Act of 1986). Some additional improvements in allocational efficiency are made possible by a consumption tax because of inflation non-neutralities in the income tax (see Cohen, Hassett, and Hubbard, 1997). 
example, Harberger's original model delineated only noncorporate and corporate sectors; some researchers developed models with more sectoral detail.

More recently, models emphasizing shifts in the relative importance of corporate and noncorporate producers within an industry have suggested greater distortions under the corporate tax then suggested by earlier approaches (see Gravelle and Kotlikoff, 1989). The additional cost arises because corporate and noncorporate producers within an industry possess differential advantages. Corporations may be better able to exploit scale economics, while noncorporate organizations may be better able to encourage entrepreneurial skill. Distorting the choice between these organizational forms thus means diminishing the use of scale economies as well.

While such theoretical models as Gravelle and Kotlikoff (1989) suggest that the tax-induced distortion of organizational form could have substantial efficiency costs, recent empirical estimates by MacKie-Mason and Gordon (1997) contradict these predictions. Using time-series data from U.S. tax returns, MacKie-Mason and Gordon find that the differential taxation of corporate and noncorporate businesses has a modest (but statistically significant) effect on the amount of assets and income in the corporate form. For example, they estimate that a 10-percentage-point decrease in the tax rate on noncorporate income would cause only 0.2 percent of total assets to shift out of the corporate form. Despite these relatively small effects, the results of MacKie-Mason and Gordon imply that the excess burden from distorting organizational-form choices equals 16 percent of business tax revenue. One difficulty in measuring the excess burden from this organizational-form distortion is that it requires evaluating how much the marginal firms value corporate characteristics, such as limited liability and access to public equity markets.

MacKie-Mason and Gordon focus on tax rate changes and organizational-form choices using data from 1959 to 1986 . Their model only predicts about half of the observed shift in organizational form after the Tax Reform Act of 1986 (TRA86). In addition to changing marginal tax rates substantially, TRA86 also changed various tax rules, such as the general utilities doctrine and passive-loss rules, that affect organizational-form choices. Several responses to TRA86 suggest that taxes do play an important role in organizational-form decisions. First, Nelson (1991) and Poterba (1992) document the proliferation of S corporations which do not face double taxation. Second, the rise of publicly-traded partnerships in the mid-1980s and the subsequent tax reforms that legislated their demise are another case study of how organizational form adapts to tax law (see Gentry, 1994). Third, the increasing importance of limited- 
liability companies (LLCs) also attests to the incentives to avoid organizational forms with double taxation after TRA86 (see Hamill, 1996). In summary, taxes appear to play an important role in organizational-form choices for some firms (though not necessarily the largest public corporations), but the magnitude of this effect and the efficiency costs are difficult to measure.

The tax bias against corporate equity investment must be placed in the context of other tax considerations (which we discuss in greater detail below). For example, when the source of corporate equity investment is retained earnings, rather than new share issues, then the funds for investment are taxed at the corporate level and as capital gains to investors. At various times and in certain industries, the combination of the corporate tax rate and the effective tax rate on capital gains has been greater than, equal to, and less than the individual income-tax rate on business income. In this way, differences among tax rates may reduce, eliminate, or even reverse the bias against investment by corporations. An additional mitigating factor is the use of debt financing; to the extent that corporations finance investments through debt, the relative tax advantage for noncorporate businesses is reduced.

Switching from the current tax system to the flat tax would eliminate the distortions of organizational form arising under the classical corporation income tax. This efficiency gain-which some models summarized in U.S. Department of the Treasury (1992) suggest is substantial-is accomplished, however, by integrating the corporate and individual income tax systems. Hence fundamental income-tax reform would also yield this gain, though the flat tax would also address the distortion in the allocation of capital between owner-occupied housing and corporate capital.

\section{CAPITAL-STRUCTURE DISTORTIONS}

In practice, the effect of the corporate tax distortion on debt-equity ratios and on economic efficiency depends in part on the degree of substitutability of debt and equity from a non-tax perspective. If, on the one hand, firms consider debt and equity to be perfect substitutes in corporate finance, taxes will affect capital structure but will have no efficiency consequences for the firm. If, on the other hand, capital structures are completely determined by non-tax considerations, differential taxation leads to differences in effective tax rates on capital among firms.

The general benchmark for analysis is the frictionless world of Modigliani and Miller (1958): with no taxation, no bankruptcy costs, and no information problems, corporate financial policy is irrelevant. With bank- 
ruptcy costs and corporate taxes, firms experience a trade-off at the margin when raising additional debt financing between an increased probability of incurring bankruptcy costs and the tax subsidy granted to debt.

In general, both corporate and individual taxes (on ordinary income and capital gains) matter for decisions about corporate capital structures. While the corporate tax favors debt financing, the individual tax favors equity financing. Although dividends and interest income are taxed similarly in the individual tax, equity income received in the form of capital gains is taxed at a lower effective rate on account of deferral (and, in some periods, lower explicit tax rates).

With corporate and individual taxes, the net tax benefit to financing through debt depends on individual tax rates on interest, dividends, and capital gains, the corporate tax rate, and dividend policy. In particular, for an investor facing tax rates of $\theta$ on interest and dividends and $c$ on capital gains, the relative attractiveness of debt financing over equity financing is measured at the margin by

$$
(1-\theta)-[(1-\tau) d(1-\theta)+(1-d)(1-c)]-b,
$$

where $\tau$ is the corporate tax rate, $d$ is the dividend payout rate, and $b$ is the marginal bankruptcy cost. Gordon and MacKie-Mason (1990) specify $b$ as a function of the capital structure and obtain an expression for selecting the capital structure that maximizes the net incentive for debt financing.

In the frictionless model $(b=0)$ considered by Miller (1977), when no dividends are paid $(d=0)$ and the effective tax rate on capital gains is zero $(c=0)$, the marginal investor is indifferent between bonds and equity if $\theta$ $=\tau$. If $\theta>\tau$, the investor will invest only in equity; if $\theta<\tau$, the investor will invest only in debt. While firms' capital structures are indeterminate in Miller's model, the equilibrium capital structure for firms as a whole depends on individual income-tax rates and the distribution of wealth across tax brackets. While the Miller model is analytically transparent, its predictions about investor clienteles and the lack of patterns in corporate capital structures is counterfactual. Generally speaking, researchers have attempted to extend the intuition by describing cross-sectional variation in the net tax incentives based on non-debt tax shields or on information incentive problems in financial contracting.

In the first research program, DeAngelo and Masulis (1980) linked non-debt tax shields with cross-sectional variation in debt policy. In their approach, the firm's effective tax rate on interest deductions at the margin depends on such non-debt tax shields as tax-loss carryforwards and 
investment tax credits. ${ }^{12}$ Despite the theoretical link between taxes and debt policy, empirical work following Miller and DeAngelo and Masulis failed to find statistical support for the theory. ${ }^{13}$ MacKie-Mason (1990) improves on previous studies by focusing on how taxes affect capitalstructure decisions at the margin and by using data on incremental financing decisions rather than firms' levels of debt. While this research design leads to clear evidence that taxes affect financing decisions, it does not provide a precise estimate of the long-term effects of fundamental tax reform on corporate financial structure. Exploiting the changes in tax incentives created by the Tax Reform Act of 1986, Givoly, Hayn, Ofer, and Sarig (1992) find further support for the effects of taxes on financing decisions.

Other sources of cross-sectional variation arise from information and incentive problems in financial contracting. Debt can discipline the moral hazard associated with equity financing (as in Jensen and Meckling, 1976), although it can also lead to inefficient increases in managerial risktaking (as in Myers, 1977). In such approaches, the desirability of debt financing for non-tax reasons may vary across firms according to differences in the extent of asymmetric information or in the tangibility of assets being financed.

An additional source of cross-sectional variation comes from differences in firms' relative exposure to idiosyncratic and aggregate risk, as in Gertler and Hubbard (1993). Even without taxes, the presence of both types of risk leads to the use of both debt and equity in corporate capital structures. Tax distortions confront firms with an ex ante trade-off between the costs of equity finance and the costs of increasing exposure to the macroeconomic risk that accompanies debt financing. Consistent with the model, Gertler and Hubbard show that, holding firm-level determinants of dividends constant, dividend payments rise in aggregate good times and fall in aggregate bad times.

An additional possible source of cross-sectional variation is crosscountry differences in capital structure for "similarly situated" firms. Rajan and Zingales (1995) offer some suggestive evidence that crosscountry differences in the net incentive for debt financing are positively associated with cross-country differences in leverage. One could extend this line of inquiry by studying differences in leverage across countries

12 Strictly speaking, this approach requires that the cross-sectional variation be exogenous. This is a strong requirement; one firm may have more investment tax credits than a "similar firm" because it has higher investment opportunities.

13 Examples include Auerbach (1985); Bradley, Jarrell, and Kim (1984); and Titman and Wessels (1988). 
for firms in the same industry or by exploiting the cross-sectional variation in the net incentive for leverage created by major tax reforms (as in Cummins, Hassett, and Hubbard, 1996, for investment).

Recent financial innovation also suggests cross-sectional variation in firms' ability to increase leverage at the margin to finance investment. Regulatory and other constraints may require some equity-like financing. One such innovation with growing popularity is a class of hybrid securities typified by Monthly-Income Preferred Stock (MIPS). ${ }^{14}$

The key to achieving these tax benefits is the insertion of a noncorporate financial intermediary between the issuer of the security and the buyer of the security. For MIPS, this intermediary is often a limitedliability company (LLC) that is wholly owned by the issuer. The LLC is taxed as a partnership under U.S. tax law because it has neither continuity of life nor freely transferable ownership claims. The LLC issues publicly traded preferred stock and lends the proceeds to the parent as subordinated debt. The parent's interest expense is tax-deductible, but it is income for the LLC. Typically, the parent's interest payments are timed to match the preferred stock dividends of the LLC. Thus MIPS owners receive dividends equal to their share of the LLC's taxable income and typically pay taxes on the cash received as ordinary income. ${ }^{15}$ For financial accounting purposes, the transaction is viewed as if the parent had issued the preferred stock because it is the sole owner of the common shares of the LLC.

Goldman Sachs developed MIPS in 1993. Subsequently, investment banks have embellished upon the MIPS structure with various features regarding the organizational form of the middleman, redemption options, and payment structures. Rather than forming an LLC, which has the paperwork associated with partnership taxation, Merrill Lynch used a trust as the financial intermediary in creating Trust-Originated Preferred Securities (TOPRS). ${ }^{16}$ While, in 1993, these hybrid securities accounted for just 4 percent of preferred-stock issues, they grew to 52 percent of

14 For a comprehensive evaluation of MIPS, see Engel, Erickson, and Maydew (1997).

15 The parent firm often has the right to defer interest payments. During such periods, the LLC can suspend the payment of dividends but still accrues income interest. If the parent defers interest payments, then the MIPS holder pays taxes before they receive cash dividends. In contrast, with traditional preferred stock, if the issuer skips a dividend, the investor does not have a tax liability.

16 Other examples include Lehman Brothers' Quarterly-Income Capital Securities (QUICS) and Goldman Sachs' Quarterly-Income Preferred Securities (QUIPS). QUICS are closer to straight debt than the other securities and do not necessarily require a financial intermediary between the issuer and buyer; however, unlike standard debt, the issuer has the right to defer payments for up to five years (see Perlmuth, 1995). 
preferred-stock issues in 1994 and over 70 percent of such issues in 1995 (see Crain and Jackson, 1996).

For the issuer, the advantage of MIPS over traditional preferred stock is that dividends are paid with pre-tax income rather than after-tax income. A corporation with a 35 -percent tax rate raising $\$ 100$ million through MIPS with a yield of 10 percent saves $\$ 3.5$ million annually in tax payments relative to issuing traditional preferred stock with the same yield. ${ }^{17}$ In practice, MIPS pay slightly higher yields (about 75 basis points) than traditional preferred stock, so some of the firm's tax benefits are lost in the form of higher pre-tax returns to investors (see Bary, 1995); whether this difference in yields is associated with the introduction of a new financial product or will be a characteristic of the long-run pricing of these securities is unclear. For individuals, the tax treatment of preferred-stock dividends and MIPS dividends is the same (provided the parent does not defer any interest payments). Because MIPS owners include allocated income from the LLC in their tax bases (rather than dividends), corporate investors do not get the dividends-received deduction for owning MIPS, which may lead them to prefer traditional preferred stock.

The MIPS example highlights the somewhat arbitrary nature of deciding whether a financing tool qualifies for the tax advantage of debt. It is easy to imagine tax regulations reclassifying MIPS as preferred stock rather than as debt by consolidating the parent firm and the financial intermediary for tax purposes. ${ }^{18}$ However, these "simple" reforms beg the question of determining when the financial intermediary is sufficiently unrelated to the parent firm so that the loan receives the tax treatment of debt.

Fundamental tax reform would eliminate the need for financial innovations such as MIPS. By eliminating the distinction between debt and equity, either CBIT or the flat tax would reduce the incentives to blur the distinction between debt and equity. Under the current tax system, it is

17 To make the $\$ 10$ million annual dividend payments on traditional preferred stock, the firm needs to earn $\$ 15.38$ million in pre-tax income and pay $\$ 5.38$ million in income taxes. If the firm issues MIPS, then it deducts the $\$ 10$ million payment from income; for the same $\$ 15.38$ million in earnings (before interest deductions), the firm would only pay tax of $\$ 1.88$ million ( 35 percent of $\$ 5.38$ million) for a tax saving of $\$ 3.5$ million. This example holds the firm's investment decision fixed; alternatively, if less-heavily taxed equity is available, the firm may invest more, which would lower the marginal return to capital.

18 Recent tax proposals from the Clinton administration (eventually excluded from the Taxpayer Relief Act of 1997) have attacked MIPS and similar securities. These proposals would base the distinction between debt and preferred stock on whether the instrument is reported as debt on the balance sheet (for financial reporting) and the maturity of the instrument ("MIPS" loans with maturities of greater than 15 years would be candidates for reclassification). Norris (1997) discusses how firms are tailoring new securities to meet these criteria. 
unclear why the level of taxation on investment should depend heavily on the form of financing and the arbitrary tax rules determining the taxation of different securities. As financial markets become even more sophisticated, the line between debt and equity for tax purposes is likely to be tested more often. Other recent examples of securities that challenge the tax classification are long-maturity (e.g., 50 or 100 years) zerocoupon bonds and contingent debt (e.g., loans with interest payments contingent on equity returns). By reducing the amounts of tax-motivated financial innovation, these reforms may not greatly affect the level or composition of corporate investment; however, there could be social benefits from reducing the resources devoted to creating, marketing, and managing these financial transactions. ${ }^{19}$

Further empirical research is needed on the degree of substitutability of debt and equity in capital structures and in household portfolios to refine estimated welfare gains from eliminating financing distortions. The economic models used in the Treasury Department's corporate-tax integration study (U.S. Department of the Treasury, 1992) suggest modest efficiency gains from eliminating corporate financing distortions. Returning to our theme, the gains from fundamental income tax reform (CBIT) and the flat tax would be identical.

\section{TIMING DISTORTIONS}

The current tax system distorts the timing of many financial decisions as taxpayers attempt to postpone (or, occasionally, accelerate) the recognition of income. In this form of tax planning, it is critical that the taxpayer has some control over whether income is recognized (or realized) for tax purposes. One example of how taxes may affect the timing of financial decisions comes from the double taxation of corporate income. While the corporate-level tax occurs when income is earned, the investor-level tax is postponed until the corporation pays a dividend. ${ }^{20}$ The other main

19 Measuring the social benefits from reducing these activities would be quixotic, but anecdotal evidence suggests these activities are expensive. In June 1995, RJR Nabisco offered to exchange $\$ 1.25$ billion of outstanding 9.25-percent preferred stock for a 10 percent issue of TOPRS. RJR paid fees totaling $\$ 20$ million in part to convince investors to swap into a new product; this marketing effort included mailings of Nabisco snack packs. However, these payments were worthwhile for RJR; the net effect of the tax benefits and the higher yield on the TOPRS was to save the firm \$26 million in 1996 with similar benefits expected in future years. See McConville (1996) for details.

20 As we discuss below, if future dividend taxes are capitalized into current stock prices, then current shareholders who sell their shares may bear part of the burden of the future dividend taxes. The key point, however, is that the sellers have some discretion over whether they sell their shares and pay the capital gains taxes associated with past retained earnings. 
class of timing distortions comes from the reliance in the current income tax on the realization principle for measuring some income, most notably capital gains income. For investors in financial assets, these incentives lead to a "lock-in" effect for assets with capital gains and to tax-motivated trading strategies. At the business level, similar tax planning issues arise in the area of mergers and acquisitions. ${ }^{21}$ In this section, we examine the effects of taxes on corporate payout policy, one of the major timing issues in corporate finance. We then discuss how financial innovation has complicated defining income with the realization principle.

\subsection{Corporate Payout Policy}

One significant source of tax asymmetry in corporate financial policy arises from the differential treatment at the individual level of equity income in the form of dividends and capital gains. Distributing earnings through dividends is taxed more highly than distributing earnings through capital gains generated by reinvested earnings or share repurchases.

Financial economists have offered two explanations for why corporate dividends are paid despite the tax bias against dividend distributions (see, e.g., the review of Poterba and Summers, 1985; and U.S. Treasury Department, 1992) ${ }^{22}$ The first-known as the "traditional view" - argues that dividends offer non-tax benefits to shareholders that offset their apparent tax disadvantage. For example, analogous to the earlier discussion of non-tax benefits of debt financing, high dividend payouts may decrease managerial discretion over internal funds. Alternatively, dividends may provide signals to investors about a firm's prospects or relative financial strength, although the need to maintain dividend payments as a signal will constrain the use of retained earnings as a corporation's source of financing for new investments. Under the traditional view, firms set dividend payments so that, for the last dollar of dividends paid, the incremental non-tax benefit of dividends equals their incremental tax cost. Thus the amount of dividends paid out is expected to decrease as the tax burden on dividends relative to capital gains increases. ${ }^{23}$ The Treasury Department's integration report largely adopted this approach.

${ }^{21}$ We discuss the effects of tax reform on the taxation of mergers and acquisitions in more detail in Gentry and Hubbard (1997b). Auerbach and Reishus (1988) discuss the effects of taxes on merger and acquisition activity.

22 It is fair to say that the question of why distributions take the form of dividendsinstead of, say, share repurchases-is an open question for research.

23 The traditional view is not represented by a single analytical model. In most implementations, the traditional view is taken to be consistent with models in which firms derive an advantage-reflected in market values-from the payment of dividends. Candidate mod- 
The second explanation, or "tax capitalization view," assumes that dividends offer no non-tax benefits to shareholders relative to retained earnings (see Auerbach, 1979; Bradford, 1981; and King, 1977). ${ }^{24}$ An additional assumption in this view is that corporations have no alternative to dividends (like share repurchases) for distributing funds to shareholders. As a result, investor-level taxes on dividends reduce the value of the firm (as they are capitalized in share values), but would generally affect neither corporate dividend nor investment decisions. Under the assumptions of the tax capitalization view, corporate tax integration or switching to the flat tax would not encourage corporations to increase dividend payouts for existing equity, but would confer a windfall on holders of existing equity.

Two types of empirical tests figure prominently in examinations of the traditional view. One approach (identified with Poterba and Summers, 1985) tests the relative predictive power of a model in which marginal equity financing comes through new shares issues (in which $q=1$, the traditional view) and a model in which retained earnings are the marginal source of equity financing (in which $q<1$, the tax-capitalization view). Poterba and Summers find that the $q$ model based on the traditional view has greater explanatory power (though there are real concerns about measurement error in proxies for $q$; see Hassett and Hubbard, 1997). A second line of inquiry compares the costs of paying dividends with the effect of distributions on share values. Bernheim and Wantz (1995) argue, for example, that if dividends are used to signal future prospects, their information content (effect on value) should relate to their tax cost. Bernheim and Wantz estimate that the information content per dollar of dividend distributions declined with the investor tax rate on dividends in U.S. tax reforms in 1981 and 1986, consistent with the traditional view. Such evidence is not necessarily inconsistent with the tax capitalization view if the reductions in marginal tax rates on dividends were anticipated by investors.

The tax capitalization view confronts the problem that dividends appear to be smoothed relative to fluctuations in fixed-investment spend-

els are those in which firms pay dividends to: signal private information about profitability (see, e.g., Bhattacharya, 1979; Miller and Rock, 1985; and Bernheim and Wantz, 1995); reduce the scope for managerial discretion (see, e.g., Easterbrook, 1984, and Jensen, 1986); or accommodate investors' "behavioral" preferences for dividends (see, e.g., Shefrin and Statman, 1984).

24 Studies of integration by the American Law Institute have sometimes adopted this view. American Law Institute (1989) assumed the tax capitalization view of the dividend decision, while American Law Institute (1992) generally argues the traditional view as a general description. 
ing. However, simple predictions about the comovement of dividends and investment are confounded when firms have financial slack or use both debt and equity financing (see, e.g., Gertler and Hubbard, 1993; Gross, 1995; and Auerbach and Hassett, 1997).

Harris and Kemsley (1997) and Harris, Hubbard, and Kemsley (1997) study the direct prediction of the tax-capitalization view that the dividend tax is capitalized in share values. Specifically, these papers observe that retained earnings are subject to dividend taxes upon distribution, but paid-in equity can be returned to shareholders as a tax-free return of capital. This observation leads to the cross-sectional prediction that dividend taxes result in a lower value for retained earnings than for total common equity, which includes paid-in capital. Using firm-level data for the United States, they find, consistent with dividend tax capitalization, that accumulated retained earnings are valued less per unit than paid-in capital. In addition, examining firm-level data for a set of countries with different degrees of corporate tax integration, cross-country variation in dividend tax rates is associated with predictable variation in the implied dividend tax discount. This set of evidence provides some support for at least partial capitalization of the dividend tax.

\subsection{Financial Innovation and Realization-Based Tax Rules}

In this subsection, we present a stylized example of how derivative securities can be used in tax planning and discuss how the prototypical reforms would affect these forms of tax avoidance. Our example has three critical features. First, assets differ in how they are taxed. Second, tax rate differences across investors create tax-motivated clienteles for the assets. Third, derivative securities can be written on the assets without triggering a change in how the underlying assets are taxed.

A simple illustration of how taxation differs across assets is the difference between assets taxed on an accrual basis and those taxed on a realization basis. For a constant tax rate, accrual-based taxation leads to a higher tax burden than realization-based taxation because the realization principle allows for deferral of taxes. For concreteness, we label the asset taxed on accrual as debt and the asset taxed upon realization as (non-dividendpaying) equity. With these labels, the assets have obvious economic differences in terms of risk, priority in bankruptcy, and decision-making responsibilities. In some cases, these non-tax differences can be quite small (recall the discussion of MIPS in the previous section); however, for the tax code to treat the assets differently, the assets need at least some cosmetic non-tax difference. Our example focuses on the differences in risk and assumes the other non-tax motivations for holding different securities are relatively unimportant. 
Tax rate differences across investors could come from a variety of sources. The simplest example of tax rate differences across investors is perhaps that between taxable investors and tax-exempt investors, such as pension funds. Other differences include those caused by progressive rates and by differences across business in loss carryforward positions. The combination of the differences in tax treatment of assets and tax rates for investors creates tax-motivated clienteles for the assets. For simplicity, we consider a transaction between a taxable investor and a non-taxable investor. Similar calculations hold for any tax rate differential. The taxable investor prefers the lightly-taxed asset, and the nontaxable investor if the natural clientele for the heavily-taxed asset.

The downside to these tax-motivated investment strategies is that the high-tax-rate investor might not like the non-tax characteristics of the lightly-taxed asset (e.g., it is too risky) and vice versa. Derivative securities offer investors a mechanism for trading the risk characteristics of the assets without giving up the tax characteristics. As an example of a derivative security, we use a swap contract. ${ }^{25}$ Suppose the debt offers a riskless return and the equity offers a risky return. For tax reasons, taxexempt investors tilt their portfolios toward debt and the taxable investors increase their relative holdings of equity. To undo this tax distortion in the riskiness of their portfolios, the investors enter into a swap contract. The tax-exempt investor promises to pay the taxable investor the return on a fixed amount of debt in exchange for the return on an investment on the same-size stake in the equity security at some specified future date (e.g., five years from the beginning of the contract). The size of the investment (i.e., the fixed amount of debt specified in the contract) is referred to as the notional principal for the contract. Through the swap contract, the high-tax-rate investor's exposure to the risk of the equity return falls and the tax-exempt investor's exposure to this risk increases. However, this contract is taxed on a cash-flow basis rather than an accrual basis.

At the end of the contract, if the equity has outperformed the debt, then the taxable investor pays the tax-exempt investor the value of the equity return in excess of the return on debt. ${ }^{26}$ This payment would

${ }^{25}$ The swap contract is convenient for expository purposes. However, the Taxpayer Relief Act of 1997 changed the rules so that investors with unrealized gains on swap contracts must recognize them before the termination of the contract. One can design similar strategies by combining put and call options. In describing the strategies with options, it is necessary to keep track of the exercise prices of the different options and the tax treatinent of the premiums in addition to the cash flows at settlement.

${ }^{26}$ Contracts settle on a net basis rather than each party making a gross payment to the other. 
decrease the taxable investor's taxable income and increase the tax base of the counterparty (not relevant in the case of the tax-exempt investor). ${ }^{27}$ The taxable investor has hedged the risk of owning the equity, replacing the risky return with the safe return on debt. However, the taxation of this safe return is deferred until the settlement of the swap contract. Effectively, the taxable investor has recharacterized the financial return on debt from being taxed on accrual to being taxed on a realization basis.

These tax avoidance strategies are even more powerful when the owner of the equity has an unrealized capital gain. The swap contract allows the investor to hedge the risk of future price changes but continue to defer the tax on the gain. Without these derivative securities, the unrealized capital gain creates the well-known "lock-in" effect of discouraging portfolio reallocation. The derivative securities allow investors to sidestep the lock-in effect: The derivative security can hedge all (or, at the investor's discretion, some) of the risk of keeping the asset with gain, but its use does not trigger a tax on the unrealized gain. Of course, for many investors, the transaction costs of this type of tax planning are prohibitively high; however, as liquidity in these financial markets improves, the costs of these strategies may fall considerably.

Tax reform greatly reduces the scope for tax planning through derivative securities. Both CBIT and the flat tax eliminate the critical elements of these strategies - the disparity in tax rates across assets and across investors. For both the issuer and the investor, debt and equity have symmetric treatment. For financial investments, both reforms have zero marginal tax rates for all investors. Thus investors can reallocate their portfolios without triggering realization-based taxes. By eliminating the rationales behind these investment strategies, fundamental tax reform would curtail the revenue losses associated with tax arbitrage. Another benefit from this tax simplification would be reducing the uncertainty firms face regarding tax regulations.

\section{FINANCING DECISIONS AND TAX INCIDENCE}

In this section, we describe two general frameworks for analyzing the incidence of the corporate income tax. In these analyses, corporate financing decisions play a pivotal role in predicting the incidence of fundamental tax reform. Thus the evidence on tax distortions of organization

27 In this example, we focus on how derivatives change the risk exposures of portfolios and the timing of tax liabilities. There are also issues as to whether the income is classified as capital or ordinary for tax purposes. 
TABLE 1

Effect of the Flat Tax on Business Organization and Financing Decisions

\begin{tabular}{cccc} 
& & \multicolumn{2}{c}{ Effect traceable to } \\
\cline { 3 - 3 } & Effect on & Move to & CBIT $\rightarrow$ \\
Factor & CBIT & flat tax \\
\hline
\end{tabular}

Factors influencing organizational form

Elimination of classical

corporation income tax

Elimination of tax distinction between

debt and equity

Elimination between retentions and

distributions
Corporate versus

noncorporate form

Factors influencing capital structure

Corporate capital structure

$\checkmark$

Corporate payout policy

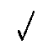

and financing decisions surveyed in the previous sections helps understand the debate over how tax reform will affect rates of return. As summarized in Table 1, the major effects of these reforms on corporate financing decisions are similar. We proceed to analyze the effects of tax reform on the risk-free interest rate and stock prices. The risk-free interest rate is important for comparing consumption-tax and income-tax reforms, since, as we discussed in section 3 it is the portion of the return to capital for which the tax treatment differs under the two reforms.

\subsection{Frameworks for Analyzing Tax Reform}

Much of the policy discussion in the United States over reform of capital income taxation has focused on the excess burden and incidence of the classical corporation tax. In the classic partial-factor tax approach of Harberger $(1962,1966)$, the corporate tax affects the required return on marginal equity-financed investments in the corporate sector, thereby distorting organizational form and investment decisions. In the central case emphasized by Harberger, the burden of the tax is borne by owners of capital generally.

An opposing view traces to Stiglitz's (1973) exposition of the corporation tax. If, in contrast to Harberger's all-equity-financed world, marginal investment projects are financed by debt, the corporate tax does not distort investment decisions; the burden of the tax is borne by inframarginal 
equity and any economic rents associated with new investment. This story is consistent with the ideas of dividend tax capitalization and frictionless decisions about capital structure, as we describe below.

Returning to our consideration of fundamental tax reform, integration has different efficiency and distributional consequences in the two approaches. In the Harberger approach, integration eliminates a costly distortion of organizational form and reduces the tax burden on investment and the tax burden on owners of capital generally. In the Stiglitz approach, efficiency consequences of integration are minimal, and the elimination of the incremental corporate tax creates a windfall gain for current equity holders. The Harberger and Stiglitz approaches are more similar in their depiction of the consequences of moving from an integrated tax system of the CBIT form to a consumption tax of the flat-tax form. In either approach, the shift in tax base eliminates the tax on the riskless return to capital, increasing investment demand.

\subsection{Tax Reform, Interest Rates, and Stock Prices}

How integration affects interest rates on business debt has been the subject of considerable debate (see, e.g., Feldstein, 1995, and Hall, 1996b). The conventional closed-economy explanation of the effect of interest rates of switching from the current tax system to an integrated tax system of the CBIT form is that the pre-tax interest rate should fall (see Hall and Rabushka, 1983, 1995, and Hall, 1996a). The intuition for this argument is as follows. Two features of the CBIT reform would directly affect corporate interest rates. First, taxes on interest income are eliminated. Second, interest deductibility is eliminated. In the market for business credit, the supply and demand schedules for credit (as a function of the interest rate) both shift down. In the simplest story, all interest income is taxed, and all interest expenses are deducted. In a closed economy, if there is no heterogeneity in tax rates, the introduction of CBIT maintains the existing after-tax interest rate; that is, the pre-tax interest rate falls by the amount of the tax. ${ }^{28,29}$

Hall's argument for flat or declining interest rates in response to CBITtype integration is in this spirit. Taking the Stiglitz (1973) modelincorporating dividend tax capitalization-as a benchmark, integration should have no effect on the marginal return on equity-financed investment. To maintain (closed-economy) capital-market equilibrium, the

28 In a small, open economy, integration increases desired international lending.

${ }^{29}$ In reality, of course, there is heterogeneity in the effective tax rates facing suppliers and demanders of credit. For example, tax-exempt investors and light-taxed foreign investors are major suppliers of credit to U.S. businesses. 
net-of-tax return on debt also will not change. Hence, as in Hall's analysis, the pre-tax interest rate falls by the amount of the tax.

Feldstein's argument for a rising interest rate in response to integration is closer to the Harberger benchmark. In this setting, integration increases the marginal return on equity-financed corporate investment (capitalization effects are minimal). Maintaining capital-market equilibrium requires the after-tax interest rate to rise.

One can add to these analyses of how integration affects interest rates the consequences of expensing of capital expenditures (as in the movement from CBIT to the flat tax). The effect of the shift from CBIT to the flat tax on interest rates depends on the interest sensitivity of the supply of funds to the domestic business sector. If the domestic business sector is a "small open economy," the introduction of the flat tax leaves interest rates at their CBIT levels, consistent with Hall's analysis. If the supply of funds is not perfectly elastic, the higher demand for funds puts upward pressure on interest rates, consistent with Feldstein's analysis of a shift to consumption taxation. Table 2 summarizes the effects of tax reform on interest rates.

Fullerton and Gordon (1983) use a computable general equilibrium model with endogenous financial behavior (calibrated to 1973 data) to simulate the effects of integrating corporate and personal income taxes. In their case, in which any revenue lost from this reform is replaced by a lump-sum tax on individuals, the risk-free interest rate changes by only a few basis points relative to the equilibrium without the reform, in both the short run and the long run. While the data underlying these results are dated, the findings fall squarely in the middle of the current debateintegration of the corporate and personal taxes neither substantially raises nor lowers interest rates.

Both Hall and Feldstein assume that a fixed fraction of marginal investments (zero in Hall's case and positive in Feldstein's case) is financed with equity. To the extent that information and incentive problems in capital markets suggest a role for debt and equity in the capital structure, removing the double taxation of corporate equity returns would then lead to a substitution of equity for debt and gains in efficiency (see the results of simulation models used in U.S. Department of the Treasury, 1992). The Harberger and Stiglitz benchmarks also imply different reactions of stock prices to tax reform. In the Harberger setting, capitalization is absent, so stock prices do not change in response to CBIT-type integration. By contrast, incorporating dividend tax capitalization into the Stiglitz framework, integration should increase stock prices. Moving from CBIT-type integration to the flat-tax price should rescue stock prices, all else being equal, owing to the expensing of "new capital" (see, 
TABLE 2

Effects of the Flat Tax on Corporate Interest Rates

\begin{tabular}{|c|c|c|c|}
\hline \multirow[b]{2}{*}{ Factor } & \multirow{2}{*}{$\begin{array}{l}\text { Effect on corporate } \\
\text { interest rates }\end{array}$} & \multicolumn{2}{|c|}{ Effect traceable to } \\
\hline & & Move to CBIT & CBIT $\rightarrow$ flat tax \\
\hline & \multicolumn{3}{|c|}{ Factors influencing demand for credit } \\
\hline $\begin{array}{l}\text { Elimination of interest } \\
\text { deductibility }\end{array}$ & $\begin{array}{l}\text { (Issue: heterogeneity } \\
\text { of rates) }\end{array}$ & $\sqrt{ }$ & \\
\hline Shift to expensing & $\begin{array}{l}+/ 0 \\
\text { (Issue: elasticity of } \\
\text { supply of funds to } \\
\text { business sector) }\end{array}$ & & $\sqrt{ }$ \\
\hline & \multicolumn{3}{|c|}{ Factors influencing supply of credit } \\
\hline $\begin{array}{l}\text { Elimination of interest } \\
\text { taxation }\end{array}$ & $\begin{array}{l}- \\
\text { (Issue: heterogeneity } \\
\text { of rates) }\end{array}$ & $\sqrt{ }$ & \\
\hline $\begin{array}{l}\text { Increase in equity } \\
\text { returns }\end{array}$ & $\begin{array}{l}+/ 0 \\
\text { (Issue: Dividend tax } \\
\text { capitalization) }\end{array}$ & $\sqrt{ }$ & \\
\hline Increased saving & $\begin{array}{l}-/ 0 \\
\text { Issue: Capital-market } \\
\text { integration) }\end{array}$ & & $\sqrt{ }$ \\
\hline
\end{tabular}

for example, Auerbach and Kotlikoff, 1987, and Hall, 1996a). ${ }^{30}$ At the current corporate tax rate of 35 percent, the move from current law to expensing for equipment investment would lead to a decline in equity values through this channel of about 8 percent (using the calculations in Hassett and Hubbard, 1997). ${ }^{31}$ Table 3 reviews the issues of how tax reform would affect stock prices.

30 Under the income tax, the effective cost per dollar of capital goods purchased equals $\$(1-\tau z)$, where $\tau$ is the corporate tax rate and $z$ is the present value of depreciation deductions for the invested dollar. Under the consumption tax, capital investment is expensed, so that $z$ rises to unity and the effective cost per dollar of capital goods purchased falls to $\$(1-\tau)$. That is, one can think of the investment incentives accompanying expensing as reducing the price of capital. If "new capital" purchased under the expensing (consumption tax) regime is otherwise the same as "old capital" in place under the depreciation (income tax) regime, the price of old capital will fall.

${ }^{31}$ This simple calculation assumes that firms can costlessly adjust their fixed capital stocks to take advantage of changes in expected profitability or in the tax treatment of investment. 
TABLE 3

Effects of the Flat-Tax Reform on Equity Prices

\begin{tabular}{lccc}
\hline \multicolumn{1}{c}{ Influencing Factor } & $\begin{array}{c}\text { Effect on } \\
\text { stock prices }\end{array}$ & \multicolumn{2}{c}{ Effect traceable to } \\
\cline { 3 - 4 } Shift to expensing & - & & $\checkmark$ \\
$\begin{array}{l}\text { Elimination of investor- } \\
\text { level dividend tax }\end{array}$ & $+/ 0$ & $\checkmark$ & CBIT $\rightarrow$ flat tax \\
$\begin{array}{l}\text { Elimination of capital-gains } \\
\text { tax }\end{array}$ & + & $\checkmark$ \\
$\begin{array}{l}\text { Reduction of tax rate on } \\
\text { business income }\end{array}$ & $+\sqrt{ }$ & $\checkmark$ \\
\hline
\end{tabular}

As we described above, available evidence suggests that both debt and equity are likely to be used in new investment and that at least part of the dividend tax is capitalized in share values. The former observation confirms the economic intuition in the Treasury Department's evaluation of the salutary effects of integration. The latter observation suggests that some windfall gains will accompany integration. That is, integration would likely raise stock prices. In addition, to the extent that base broadening in tax reform reduces marginal tax rates, tax reform can reduce the tax rate on business income (or business cash flow), raising the present values of after-tax returns on business investments and equity values in the short run.

\section{TAX PLANNING AFTER TAX REFORM}

One of the most radical features of fundamental tax reform is its shift in the types of transactions subject to the tax system. The current incometax base includes both "real" and "financial" transactions. For example, measuring corporate income as a proxy for the return on the productive assets of the firm is an exercise in taxing real transactions, whereas measuring the returns on the debt and equity contracts financing this

Economic studies of investment have shown, however, that firms face costs of installing new capital goods, leading firms to smooth changes in their capital stocks over time. If these "adjustment costs" are high, old capital remains valuable relative to new capital, and stock prices need not fall. If adjustment costs are low, the shift to expensing per se reduces stock prices. In their review of existing studies, Hassett and Hubbard (1997) conclude that adjustment costs are relatively low, so that focusing on the changes in $\tau$ and $z$ is sensible for estimating consequences of expensing for stock prices. 
investment focuses on a set of financial transactions. Neither CBIT nor the flat tax would attempt to tax financial transactions; instead, these tax systems focus on taxing real transactions by businesses and households. CBIT would measure the capital income of businesses and the labor income of households; the flat tax would levy a cash-flow tax on businesses and a labor income tax on households. Financial transactions between businesses, between households, or between a business and a household would not be targets of the tax system.

Excluding financial transactions from the tax base is not necessarily a feature of fundamental tax reform. Alternative integration proposals, such as dividend deduction or imputation systems, would continue to base the tax system on a combination of real and financial transactions. Consumption-tax proposals based on the personal-expenditure model, such as the recent USA Tax proposal, would also tax a combination of real and financial transactions. Thus the advantages and disadvantages of focusing the tax system on real transactions are specific to the proposals we outlined as prototypes for reform rather than being generic features of moving to a pure income or consumption tax.

Fundamental tax reform dramatically reduces the incentives for tax planning. This reduction comes primarily from reducing the disparity in tax rates for various types of transactions. For example, under either the flat tax or CBIT, investors in financial assets face a marginal tax rate of zero. In addition, issuers of financial assets do not get deductions from their tax bases for returns paid on different financial assets (e.g., interest is not deductible). For real assets used for business purposes, all firms have a common marginal tax rate that applies to cash flow under the flat tax or business income under CBIT. Furthermore, allowing losses to be carried forward with interest reduces the tax rate differential between firms with positive and firms with negative tax bases. In addition, to the extent that it lowers top marginal tax rates, tax reform reduces the incentives for clientele-based tax planning even in cases when a transaction is taxed differently across investors. By not taxing financial transactions, tax reform eliminates the tax rate differentials on ordinary and capital income and on debt and equity returns. Thus tax reform eliminates the tax preference for different forms of financing and the incentives for forming tax clienteles in portfolio choice.

While these prototypical tax reforms eliminate the distinctions between debt and equity and the tax status of many business organizational forms, they rely on separating business transactions into "real" and "financial" categories. It is natural to ask whether reliance on this classification will create a new genre of tax planning techniques. For many transactions, such as the purchase of a printing press or a bank 
loan, the classification seems incorruptible. Tax planning, however, can involve devising complex legal transactions to accomplish simple goals. To fix ideas, we examine a stylized case of the tax treatment of the sale of an intangible asset under the flat tax and CBIT. We also briefly review the challenges created by financial intermediaries for tax reform that have been discussed in more detail elsewhere (see, e.g., Bradford, 1996).

One area in which the distinction between real and financial transactions can become blurred is the creation of intangible capital, such as the transfer of a new technology. For simplicity, consider a small research firm owned by an inventor. The firm has expertise in research but not in manufacturing, so it plans to sell its research output to other firms. The firm produces a new invention with a market value far in excess of the research cost. To ensure that the inventor receives the rewards to the invention, we assume that the new technology cannot be replicated by other firms. If this new technology is embodied in a piece of tangible equipment, then selling the invention would obviously fit the definition of a "real" transaction. Under a consumption-tax version of tax reform, this transaction increases the tax base of the inventor and decreases the tax base of the buyer by equal amounts. Under an income-tax reform, this transaction increases the tax base of the inventor by the sales price, but because the buyer depreciates the machinery, the present value of the buyer's tax base falls by less than the purchase price of the machine.

The distinction between real and financial transactions is less clear if the invention is protected by a patent rather than being embodied in physical capital. The question becomes whether selling the patent is a real or a financial transaction. If it is a real transaction, then the tax treatment is identical to the sale of a machine; if it is a financial transaction, then the sales price will not be included in the seller's tax base or give rise to deductions for the buyer. The seller would prefer to label the transaction as "financial" to avoid including it as taxable income, but the buyer would prefer to label it as a "real" transaction to generate deductions (either immediately under a consumption tax or over time under an income tax). Therefore, the first rule for eliminating this tax avoidance scheme is to force the buyer and seller to treat the transaction symmetrically.

The choice of whether the transaction is real or financial will greatly affect the price of the patent-the pre-tax price of a real transaction will be higher than the price in a financial transaction (in which the pre-tax price equals the after-tax price), because a real transaction reduces the tax liability of the buyer but increases the tax liability of the seller. Under a consumption tax, assuming the buyer and seller face the same marginal tax rate, the decreased tax liability of the buyer exactly offsets the 
increased tax liability of the seller. Thus the parties should be indifferent to whether the transaction is classified as real or financial. For an income tax, treating the transaction as financial may lower the total tax liabilities of the buyer and seller because the buyer will get deductions only over the life of the patent rather than at the time of purchase. That is, the income tax will levy a tax on the time value of waiting for these depreciation allowances by collecting tax from the seller but reducing the buyer's tax base only over time.

Because under an income tax the tax revenue generated by this transaction depends on whether it is treated as a real or as a financial transaction, the tax code would need rules, such as amortization schedules based on the projected life of a patent, for determining the tax treatment of a transaction. However, tax planning sometimes pushes the limits of regulations. For example, rather than purchase the patent and take tax deductions according to the amortization schedule, the acquiring firm could buy all of the equity of the firm that owns the patent. ${ }^{32}$ By selling equity rather than the patent, the purchase price is not included in the seller's tax base. After the merger, the buyer could use the patent and would be allowed tax deductions associated with the new business; however, the buyer would not get depreciation allowances for tax purposes for the entire purchase price of the business. Given the time value of money, the present value of the reduction in the seller's tax liability should exceed the present value of any additional taxes paid by the buyer created by opting for a financial transaction rather than a real transaction. This example highlights the ability of businesses to structure transactions as the transfer of either real or financial assets, depending on which provides the better tax result. Provided that the transaction is between two businesses with the same tax rate, this form of tax planning is effective under CBIT, but not under the flat tax, because the firms should be indifferent to the distinction between real and financial transactions under the flat tax.

If the businesses do not have the same tax rate or one party to the transaction is a household, then the distinction between real and financial transactions can create tax planning opportunities even under the flat tax. For a transaction between a business and a household, the tax base of the business includes cash received for real transactions (the sale of goods or services) but not the proceeds from financial transactions (proceeds from borrowing or interest received); neither type of transac-

32 Alternatively, the firm with the patent could create a subsidiary that owns the patent and sell the shares of the subsidiary to the acquirer. While the government could reclassify sham transactions, our objective here is to give an idea of how tax advisors will take advantage of tax reform. 
tion creates a deduction from the household's tax base. Thus, in the extreme, the tax incentives are for a household to buy grocery stores and consume the inventory instead of buying groceries. A more realistic example, discussed by McLure and Zodrow (1996), involves dividing a household's payment for durable consumption goods into the purchase price of the good (included in the seller's tax base) and the interest on a loan (not included in the seller's tax base). ${ }^{33}$ The general tax-avoidance issue, applicable in some degree to the current system, is whether a business can transfer consumption to its owners (or employees) without that consumption's being measured appropriately by the tax system. ${ }^{34}$ Tax planning that uses (or abuses) the distinction between real and financial transactions may be especially acute for financial services because the firm's "real" product (financial services) is inexorably linked to financial transactions. Bradford (1996) discusses the difficulties of taxing financial services. He concludes that the problems of taxing the financialservice industry are not particular to either type of tax system. However, some types of tax reforms (especially those similar to a value-added tax, as are the flat tax and CBIT) raise the political profile of these problems. In addition, for transactions between firms, provided the two businesses face the same marginal tax rate, the tax treatment of financial intermediation is of relatively minor importance. This conclusion follows from the same type of arguments we described above for why the choice of treating the sale of a patent under the flat tax as a real or a financial transaction does not affect the total tax liability placed on the transaction. ${ }^{35}$ Thus the issue for financial services becomes mainly an issue of measuring household consumption.

Fundamental tax reform, as represented by either CBIT or the flat tax, could potentially uproot many of the standard corporate tax planning techniques. These reforms lead to a more consistent and symmetric treatment of various financial transactions. Quantifying the social benefits from these changes, in terms of equity and efficiency gains, is a daunting

${ }^{33}$ McLure and Zodrow argue that these types of tax avoidance schemes might be so difficult to monitor that consumption-tax reform could be better implemented under what they call a "hybrid" consumption tax. Under this hybrid, households would face a tax base similar to the flat tax (i.e., financial transactions are excluded from the tax base), but the business-level tax base would include both real and financial transactions. This proposal would maintain the neutrality between debt and equity financing by including all proceeds from raising capital in the tax base of the firm and allowing the firm deductions for all disbursements on financial contracts (returns of capital, principal, interest, and dividends).

${ }^{34}$ For a discussion of this type of tax avoidance under the current hybrid income tax, see Clotfelter (1983) and Bradford (1986).

35 Because financial services are not durable (i.e., they would not need to be depreciated as an input to production), this conclusion holds for CBIT as well as the flat tax. 
task because the associated distortions arise in areas that are difficult to measure, such as risk characteristics of portfolios and transaction costs in financial markets.

We conclude this section with two cautionary notes. First, while tax reforms promise to reduce known tax-planning techniques, some latitude would still exist for tax avoidance (especially in distinguishing real and financial transactions), and tax lawyers can be ingenious in creating new methods (see, e.g., Feld, 1995, and Ginsburg, 1995). Second, we have focused on the benefits of tax reform when tax rates are constant over time; the transition to this regime (or future changes in tax rates) might create opportunities for tax avoidance that could result in costly losses of tax revenues.

\section{CONCLUSION}

Discussion of "fundamental tax reform" by policymakers-and sometimes by economists-often treats income-tax reform and consumptiontax reform as polar opposites. In this paper, we evaluate consequences of tax reform for corporate financial policy-business organizational, financing, and tax planning activities-to distinguish between effects of income tax reform and those of consumption tax reform. We focus on one fundamental income tax reform proposal (the Treasury Department's comprehensive business income tax and one consumption tax reform proposal (the flat tax).

Our principal conclusions are four. First, relative to CBIT, the flat tax exempts only the risk-free return to capital; the two taxes treat similarly returns arising from risk bearing, luck, or inframarginal elements. Second, the effect of fundamental tax reform on the risk-free interest rates depends on whether dividend taxes are capitalized in share values and on the elasticity of the supply of funds to the domestic business sector with respect to the net return. As long as the supply of funds to the business sector is highly elastic, most of the effect on interest rates is a consequence of income tax reform (moving to CBIT). Third, effects of tax reform on organization and financing decisions stem from income tax reform, though the flat tax permits simpler rules for mergers and acquisitions than CBIT. Finally, with regard to financial innovation for tax planning, to the extent that such innovations arise to muddle the distinction between debt and equity for tax purposes, they are no longer necessary under either CBIT or the flat tax. One difference between the two types of reform is that the flat tax is neutral between real and financial transactions, while CBIT may create some tax motivations for structuring merger and acquisition transactions as financial rather than real. 
Our analysis has implications for the policy debate over tax reform and for economic research. Because fundamental income tax reform and consumption tax reform have broadly similar effects on many business decisions, policymakers should not consider the reforms in opposition to one another. For economists, obtaining quantitative estimates of the effects of either reform on business investment, organizational, and financing decisions and of efficiency gains requires more robust conclusions about the effect of dividend taxes on share prices, the elasticity of the supply of funds to the domestic business sector, and the substitutability of debt and equity in capital structures. These questions are, of course, not new, but they remain important topics for research in measuring gains from fundamental tax reform. In addition, further research on transition questions is needed to shed light on the consequences of tax reform, such as the speed with which debt and equity contracts can be renegotiated and the extent to which anticipated future changes in tax rates cause significant tax-planning distortions.

\section{REFERENCES}

American Law Institute, Federal Income Tax Project (1989). "Reporter's Study Draft, Subchapter C (Supplemental Study)." Philadelphia: American Law Institute. Memorandum written by Professor William D. Andrews of the Harvard Law School.

(1992). "Reporter's Study Draft, Integration of the Individual and Corporate Income Taxes." Philadelphia: American Law Institute. Memorandum written by Professor Alvin C. Warren of the Harvard Law School.

Auerbach, Alan J. (1979). "Wealth Maximization and the Cost of Capital." Quarterly Journal of Economics 93(August):433-446.

- (1985). "Real Determinants of Corporate Leverage." In Corporate Capital Structures in the U.S., Benjamin Friedman (ed.). Chicago: University of Chicago Press.

(1989). "The Deadweight Loss from 'Non-neutral' Capital Income Taxation." Journal of Public Economics 40:1-36.

- (1996). "Tax Reform, Capital Allocation, Efficiency, and Growth." In Economic Effects of Fundamental Tax Reform, Henry J. Aaron and William G. Gale (eds.). Washington, DC: Brookings Institution.

- and Kevin A. Hassett (1997). "On the Marginal Source of Investment Funds." University of California, Berkeley. April. Mimeo.

, and Laurence J. Kotlikoff (1987). Dynamic Fiscal Policy, Cambridge: Cambridge University Press.

, and David Reishus (1988). "The Effects of Taxation on the Merger Decision." In Corporate Takeovers: Causes and Consequences, Alan J. Auerbach (ed.). Chicago: University of Chicago Press.

Bary, Andrew (1995). "What a Deal: New Breed of Preferred Issues Helps Everybody but the Tax Man." Barron's, February 27: 17-18.

Bernheim, B. Douglas, and Adam Wantz (1995). "A Tax-Based Test of the 
Dividend-Signaling Hypothesis." American Economic Review 85(December): 532-551.

Bhattacharya, Sudipto (1979). "Imperfect Information, Dividend Policy, and the

'Bird in the Hand' Fallacy." Bell Journal of Economics 10(Spring):259-270.

Bradford, David F. (1981). "The Incidence and Allocation Effects of a Tax on Corporate Distributions." Journal of Public Economics 15(February):1-22.

- (1986). Untangling the Income Tax. Cambridge: Harvard University Press. (1996). "Treatment of Financial Services under Income and Consumption Taxes." In Economic Effects of Fundamental Tax Reform, Henry J. Aaron and William G. Gale, (eds.). Washington, DC: Brookings Institution.

Bradley, Michael, Gregg A. Jarrell, and E. Han Kim (1984). "On the Existence of an Optimal Capital Structure: Theory and Evidence." Journal of Finance 39 (July):857-878.

Clotfelter, Charles T. (1983). "Tax-Induced Distortions and the Business-Pleasure Borderline: The Case of Travel and Entertainment." American Economic Review 73(December):1053-1065.

Cohen, Darrel, Kevin A. Hassett, and R. Glenn Hubbard (1997). "Inflation and the User Cost of Capital: Does Inflation Still Matter?" Columbia University. January. Mimeo.

Crain, John L., and Gisele Jackson (1996). "Monthly Income Preferred Securities: A New Hybrid That Combines the Best of Equity and Debt." The CPA Journal, May:68-71.

Cummins, Jason G., Kevin A. Hassett, and R. Glenn Hubbard (1996). "Tax Reforms and Investment: A Cross-Country Comparison." Journal of Public Economics 62:237-273.

DeAngelo, Harry, and Ronald W. Masulis (1980). "Optimal Capital Structure under Corporate and Personal Taxation." Journal of Financial Economics 8:3-29.

Easterbrook, Frank H. (1984). "Two Agency-Cost Explanations of Dividends." American Economic Review 74(September):650-659.

Engel, Ellen, Merle Erickson, and Edward Maydew (1997). "Debt-Equity Hybrid Securities." University of Chicago. May. Mimeo

Engen, Eric, and William G. Gale (1996). "The Effect of Fundamental Tax Reform on Saving." In Economic Effects of Fundamental Tax Reform, Henry J. Aaron and William G. Gale (eds.). Washington, DC: Brookings Institution.

Feld, Alan L. (1995). "Living with the Flat Tax." National Tax Journal 48(December):603-617.

Feldstein, Martin (1995). "The Effect of a Consumption Tax on the Rate of Interest." NBER Working Paper no. 5397.

Fullerton, Don, and Roger H. Gordon (1983). "A Reexamination of Tax Distortions in General Equilibrium Models." In Behavioral Simulation Methods in Tax Policy Analysis, Martin Feldstein (ed.). Chicago: University of Chicago Press. form on the Allocation of Resources." In The Effects of Taxation on Capital Accumulation, Martin Feldstein, (ed.). Chicago: University of Chicago Press.

Gentry, William M. (1994). "Taxes, Financial Decisions and Organizational Form: Evidence from Publicly Traded Partnerships." Journal of Public Economics 53:223-244.

- and R. Glenn Hubbard (1997a). "Distributional Implications of Introducing a Broad-Based Consumption Tax." In Tax Policy and the Economy, vol. 11, James M. Poterba (ed.). Cambridge: MIT Press. 
and - (1997b). Fundamental Tax Reform and Corporate Finance. Washington, DC: American Enterprise Institute.

Gertler, Mark, and R. Glenn Hubbard (1993). "Corporate Financial Policy, Taxation, and Macroeconomic Risk." RAND Journal of Economics 24(Summer):286303.

Ginsburg, Martin D. (1995). "Life Under a Personal Consumption Tax: Some Thoughts on Working, Saving, and Consuming in Nunn-Domenici's Tax World." National Tax Journal 48(December):585-602.

Givoly, Dan, Carla Hayn, Aharon R. Ofer, and Oded Sarig (1992). "Taxes and Capital Structure: Evidence from Firms' Response to the Tax Reform Act of 1986." Review of Financial Studies 5:331-355.

Gordon, Roger H., and Jeffrey K. MacKie-Mason (1990). "Effects of the Tax Reform Act of 1986 on Corporate Financial Policy and Organizational Form." In Do Taxes Matter? The Impact of the Tax Reform Act of 1986, Joel B. Slemrod (ed.). Cambridge, MA: MIT Press.

Gravelle, Jane G. (1981). "The Social Cost of the Non-neutral Taxation: Estimates for Nonresidential Capital." In Depreciation, Inflation, and the Taxation of Income

from Capital, Charles R. Hulten (ed.). Washington, DC: Urban Institute.
, and Laurence J. Kotlikoff (1989). "The Incidence and Efficiency Costs of Corporate Taxation When Corporate and Noncorporate Firms Produce the Same Good." Journal of Political Economy 97(August):749-780.

Gross, David B. (1995). "The Financing and Investment Decisions of Liquidity Constrained Firms." mimeograph, University of Chicago.

Hall, Robert E. (1996a). "The Effects of Tax Reform on Prices and Asset Values." In Tax Policy and the Economy, vol. 10, James M. Poterba (ed.). Cambridge, MA: MIT Press.

(1996b). "The Effects of Tax Reform on Housing." Stanford University. December. Mimeo

- and Alvin Rabushka (1983). Low Tax, Simple Tax, Flat Tax. New York: McGraw-Hill.

- and - (1995). The Flat Tax, 2nd ed. Stanford: Hoover Institution Press.

Hamill, Susan P. (1996). "The Limited Liability Company: A Catalyst Exposing the Corporate Integration Question." Michigan Law Review 95(November):393-446. Harberger, Arnold C. (1962). "The Incidence of the Corporation Income Tax." Journal of Political Economy 70(June):215-240.

- (1966). "Efficiency Effects of Taxes of Income on Capital." In Effects of the Corporation Income Tax, Marian Krzyzaniak (ed.). Detroit: Wayne State University Press.

Harris, Trevor S., and Deen Kemsley (1997). "Dividend and Capital Gains Taxation in Firm Valuation: New Evidence." Columbia University. April. Mimeo.

- R. Glenn Hubbard, and - (1997). "Are Dividend Taxes and Imputation Credits Capitalized in Share Values?" Mimeograph, Columbia University, July 1997.

Hassett, Kevin A., and R. Glenn Hubbard (1997). "Tax Policy and Investment." In Fiscal Policy: Lessons from Economic Research, Alan J. Auerbach (ed.). Cambridge, MA: MIT Press.

Hubbard, R. Glenn, and Kenneth L. Judd (1987). "Social Security and Individual Welfare: Precautionary Saving, Borrowing Constraints, and the Payroll Tax." American Economic Review 77(September):630-646. 
, Jonathan S. Skinner, and Stephen P. Zeldes (1995). "Precautionary Saving and Social Insurance." Journal of Political Economy 103(April):360-399.

Jensen, Michael C. (1986). "Agency Costs of Free Cash Flow, Corporate Finance, and Takeovers." American Economic Review 76(May):323-329.

- , and William H. Meckling (1976). "Theory of the Firm: Managerial Behavior, Agency Costs, and Ownership Structure." Journal of Financial Economics 3(October):305-360.

King, Mervyn A. (1977). Public Policy and the Corporation. London: Chapman and Hall.

Kleinbard, Edward (1991). "Equity Derivative Products: Financial Innovation's Newest Challenge to the Tax System." Texas Law Review 69:1319-1368.

MacKie-Mason, Jeffrey K. (1990). "Do Taxes Affect Corporate Financing Decisions?" Journal of Finance 45(December):1471-1494.

—_ and Roger H. Gordon (1997). "How Much Do Taxes Discourage Incorporation?" Journal of Finance 52(June):477-505.

McConville, Daniel J. (1996). "Trading Preferred for MIPS, TOPRS, and QUIPS Takes Hard Marketing." Corporate Cashflow 17(February):32, 36.

McLure, Charles and George Zodrow (1996). "A Hybrid Approach to the Direct Taxation of Consumption." In Handbook of Tax Reform, Michael J. Boskin (ed.). Stanford: Hoover Institution Press, 1996.

Miller, Merton H. (1977). "Debt and Taxes." Journal of Finance 32(May):261-275. , and Kevin Rock (1985). "Dividend Policy Under Asymmetric Information." Journal of Finance 40(September):1031-1051.

Modigliani, Franco, and Merton H. Miller (1958). "The Cost of Capital, Corporation Finance, and the Theory of Investment." American Economic Review 48(June):261-297.

Myers, Stewart C. (1977). "Determinants of Corporate Borrowing." Journal of Financial Economics 5(November):147-175.

Nelson, Susan C. (1991). "S-Corporations since the Tax Reform Act of 1986." Washington DC: U.S. Department of the Treasury, Office of Tax Analysis.

Norris, Floyd (1997). "GM's Preferred Stock Gives It a Tax Break." New York Times, June 5.

Paul, Deborah L. (1996). "Another Uneasy Compromise: The Treatment of Hedging in a Realization Income Tax." Florida Tax Review 3:1-50.

Perlmuth, Lyn (1995). "Wriggling Out of Preferred." Institutional Investor November: 35-36.

Poterba, James M. (1992). "Why Didn't the Tax Reform Act of 1986 Raise Corporate Taxes?" In Tax Policy and the Economy, vol. 6, James M. Poterba (ed.). Cambridge, MA: MIT Press.

- , and Lawrence H. Summers (1985). "The Economic Effects of Dividend Taxes." In Recent Advances in Corporate Finance, Edward Altman and Marti Subrahmanyam (eds.). Homewood, IL: Richard D. Irwin.

Rajan, Raghuram, and Luigi Zingales (1995). "What Do We Know about Capital Structure?: Some Evidence from International Data." Journal of Finance 50 (December):1421-1460.

Shefrin, Hersh M., and Meir Statman (1984). "Explaining Investor Preference for

Cash Dividends." Journal of Financial Economics 13(June):253-287.

Shoven, John B., and John Whalley (1992). Applying General Equilibrium. New York: Cambridge University Press. 
Shuldiner, Reed (1992). "A General Approach to the Taxation of Financial Instruments." Texas Law Review 71:243-350.

Slemrod, Joel, and Jon Bakija (1996). Taxing Ourselves. Cambridge, MA: MIT Press.

Stiglitz, Joseph E. (1973). "Taxation, Corporate Financial Policy, and the Cost of Capital." Journal of Public Economics 2(February):1-34.

Strnad, Jeff (1994). "Taxing New Financial Products: A Conceptual Framework." Stanford Law Review 46:569-605.

Titman, Sheridan, and Roberto Wessels (1988). "The Determinants of Capital Structure Choice." Journal of Finance 43(1988):1-19.

U.S. Department of the Treasury (1992). Integration of the Individual and Corporate Tax Systems: Taxing Business Income Once. Washington, DC: U.S. Government Printing Office.

Warren, Alvin (1993). "Financial Contract Innovation and Income Tax Policy." Harvard Law Review 107:460-492.

Weisbach, David A. (1995). "Tax Responses to Financial Contract Innovation." Tax Law Review 50:491-539. 



\section{TRANSITIONAL ISSUES IN FUNDAMENTAL TAX \\ REFORM: A FINANCIAL- \\ ACCOUNTING PERSPECTIVE}

\section{Melbert Schwarz}

Congressional Joint Committee on Taxation

\section{Peter R. Merrill and Chris R. Edwards}

Price Waterhouse LLP

\section{EXECUTIVE SUMMARY}

In recent years, a number of legislative proposals have been introduced to replace the federal income tax system with a consumption-based tax system. In the 104th Congress, these included the flat tax, introduced by House Majority Leader Dick Armey, and the National Retail Sales Tax (RST), introduced by Reps. Billy Tauzin and Dan Schaefer. Recent analyses of tax restructuring proposals have suggested that transitioning from the income tax system to a new tax system could cause substantial changes to taxpayer wealth. In this paper, we discuss financial accounting for income and consumption taxes, and we examine the potential effects of tax restructuring on the book values of corporations. The paper presents estimates of the financial statement effects of replacing the corporate income tax with the National RST, or alternately the flat tax, for a sample of 96 large corporations in 1995.

Melbert Schwarz is an attorney on the staff of the Congressional Joint Committee on Taxation. Peter Merrill and Chris Edwards are economists with Price Waterhouse LLP. This paper does not necessarily reflect the views of the Joint Committee on Taxation or Price Waterhouse LLP and its partners. The authors gratefully acknowledge the assistance of Andrew Lyon. 


\section{INTRODUCTION}

In the 104th Congress, several legislative proposals were introduced to replace the federal income tax system with a consumption-based tax system. These proposals included the unlimited savings allowance (USA) tax (S. 722) introduced by former Senator Sam Nunn and Senator Pete Domenici, the flat tax (H.R. 2060) introduced by House Majority Leader Dick Armey, and the national retail sales tax (H.R. 3039) introduced by Reps. Dan Schaefer and Billy Tauzin.

With the exception of the USA tax, these proposals contain no transition rules for businesses to address wealth effects that would arise from imposition of a new tax system. Nonetheless, experience with previous major tax reforms, such as the Tax Reform Act of 1986, suggests that Congress would ultimately provide extensive transition rules, both to minimize disruptions to the economy, and to garner political support for reform.

Recent analyses of tax restructuring proposals have suggested that the transition "problem" would be large. For example, Jane Gravelle (1995) estimated that replacing the corporate income tax with a 20-percent flat tax would cause the stock market to fall 20 to 30 percent. Analyses by David Bradford (1996) and Robert Hall (1996) find similar reductions in the value of existing wealth.

The effects of tax reform on the book value of the firm are discussed in section 2 of this paper, and are distinguished from the effects of tax reform on the market value of the firm. ${ }^{1}$ Section 3 presents estimates of transitional wealth effects from replacing the income tax with the flat tax or the retail sales tax (RST). The estimates utilize financial statement data for 96 U.S. corporations in 12 industries. The extent to which wealth effects may be mitigated by allowing the deduction of unrecovered basis is also estimated. Section 4 presents our conclusions and discusses practical difficulties with providing transition relief. ${ }^{2}$

\section{FINANCIAL ACCOUNTING FOR INCOME AND CONSUMPTION TAXES}

\subsection{Financial Accounting for Income Taxes}

Financial accounting for income taxes is governed by the Financial Accounting Standards Board (FASB) in its Statement of Financial Accounting Standards No. 109 (FAS 109). The summary to FAS 109 provides that

${ }^{1}$ See Lyon, Merrill, Schwarz, and Edwards (1997).

2 The paper does not quantify the revenue or welfare costs of providing transition relief. These costs would need to be weighed in determining whether to provide transition rules. 
" $[t]$ he objectives of accounting for income taxes are to recognize (a) the amount of taxes payable or refundable for the current year and (b) deferred tax liabilities and assets for the future tax consequences of events that have been recognized in an enterprise's financial statements or tax returns."

If deferred tax liabilities and assets were not taken into account, then the financial-accounting tax expense for any period would generally be equal to the income taxes required to be paid for that period. However, the need to recognize the effect of future tax consequences through the deferred-tax accounts means that the financial-accounting tax expense will be either more (in the case of a deferred tax liability) or less (in the case of a deferred-tax asset) than is actually required to be paid.

FAS 109 required that deferred-tax assets and liabilities arising from temporary differences between book and tax accounting be recorded in the balance sheet. An increase in the net deferred tax liability account increases tax expense, and an increase in the net deferred tax asset account reduces tax expense in the current period, compared to the amount required to be paid.

2.1.1 Deferred-Tax Accounts A deferred tax liability is required where there are temporary differences that will result in taxable amounts in future years. For example, if the gain on a sale is reported for tax purposes using the installment method, current income-tax payments will be reduced, but additional taxes will have to be paid in the future. These additional taxes, measured using current income-tax rules and rates, are recognized as a deferred tax liability. ${ }^{3}$ The financial-accounting expense attributable to these additional taxes is recognized at the same time, making the financial-accounting tax expense for the period greater than the amount actually paid.

A deferred-tax asset is recorded for temporary differences that will result in deductible amounts in the future, as well as the anticipated reduction in future tax liability attributable to the carry forward of such items as net operating losses and tax credits. For example, a taxpayer subject to the corporate alternative minimum tax (AMT) generates a

${ }^{3}$ FAS 109 used the enacted rate expected to apply to taxable income in the periods in which the deferred tax liability or asset is expected to be settled or realized (FAS 109, paragraph 18). This may require the consideration of federal, state, and foreign tax rates. Because deferred taxes are not generally provided on the foreign source income of nonU.S. subsidiaries that will be indefinitely reinvested outside the U.S., the U.S. rate on such foreign-source income can be said to be zero. Since multinational corporations typically use non-U.S. subsidiaries to conduct foreign activities, and do not provide for deferred U.S. taxes with respect to such activities, changes in the U.S. taxation of foreign-source income generally will not have a material effect on the deferred tax account. 
credit equal to the excess of tentative minimum tax over regular tax. This credit, which does not expire, may be used in the future to reduce the amount of tax required to be paid in any periods where regular tax exceeds AMT.

If it is more likely than not that the benefit of some or all of the deferred-tax asset will not be realized, a valuation allowance is required to reduce the balance in the account to the amount that is likely to be realized. Because carryforwards, other than the minimum tax credit, expire if not used within a fixed period of time, valuation allowances are frequently required to offset some or all of the deferred benefit that would otherwise accompany the carryforward. The financial accounting tax expense is reduced, compared to the amount actually required to be paid, by an amount equal to the net increase in any deferred-tax-asset account for the period.

FAS 109 measures deferred tax liabilities and assets using the enacted tax rates expected to apply to taxable income in the periods in which the deferred tax liability or asset is expected to be settled or realized. The balance in any deferred-tax account must be adjusted to reflect any change in rates in the period in which the rate change is enacted. For example, if legislation were enacted cutting the present tax rate in half, the balance in both the tax liability and asset accounts generally would also be cut in half, since the future consequences the accounts represent would now occur at the new rate. 4

FAS 109 identifies the temporary differences that give rise to deferred assets and liabilities according to the enacted laws. The identity and amount of the temporary differences must be adjusted at the time of enactment for changes in law.

2.1.2 Other Financial-Statement Accounts In addition to tax expense and the current- and deferred-tax-asset or -liability accounts, a number of other financial statement accounts may be affected by the income tax. For example, extraordinary items are generally required to be reported net of their tax effect.

\subsection{Financial Accounting for Fundamental Tax Reform}

The impact of the enactment of fundamental tax reform on reported financial accounting information will depend upon the type of reform en-

4 Some exceptions to this general rule exist with regard to deferred-tax assets. Credit carryforwards, because they are stated in terms of dollars rather than as future deductions to which the new, lower rate would apply, would not have to be restated. Further, any valuation allowance would have to be recalculated to apply the reduced tax rate, but the resultant change would not necessarily be in proportion to the change in the rate. 
acted, the transitional rules that accompany that reform, and the reaction of those institutions responsible for the setting of financial accounting standards, most notably the Financial Accounting Standards Board (FASB) and its Emerging Issues Task Force (EITF).

Issues that would have to be decided include:

- Will deferred-tax consequences, including tax expense and deferredtax accounts, continue to be recorded for financial accounting purposes, or will transactions instead be stated net of their tax effect?

- If deferred-tax consequences continue to be recorded, will their measurement follow a methodology similar to that currently employed by FAS 109 ?

- Will any change in the balance of the deferred-tax account (including its elimination) be reflected through the income statements or recorded directly to equity?

- If the change in the deferred-tax account is reflected through the income statement, will its effect be recognized immediately or over time? Will this item be recorded as an extraordinary item or a cumulative adjustment?

Enactment of fundamental tax reform is expected to be directly reflected in the tax accounts, i.e., deferred tax assets and liabilities and tax expense. The future tax consequences of those events that have been recognized previously in the financial statement, but have not yet been reflected in the tax return, will almost certainly be different after the enactment of fundamental reform. This will necessitate a change in the balance of the deferred tax liability or asset and a corresponding adjustment to either current income or retained earnings. The extent of this change will be heavily influenced by the type of transitional rules that are included in the enacted reform.

A decision to eliminate deferred-tax accounting and cease measuring tax expense for financial accounting still requires an adjustment to the present-tax accounts. If the deferred-tax accounts are no longer required, they will most likely be eliminated and their elimination will require an offsetting entry. The amount of any net deferred tax liability that is eliminated will either increase income or be taken directly as an increase to equity. The amount of any net deferred-tax asset will decrease income or retained earnings.

Most fundamental tax reform proposals would eliminate the taxation of amounts that are repatriated, as dividends or otherwise, from foreign affiliates. While this would likely result in greater repatriation, it is not expected to affect directly the deferred-tax-liability account. Firms are 
not required to provide deferred taxes for amounts that could result from the remittance of undistributed earnings of foreign subsidiaries and joint ventures if the business intends to continue to reinvest those earnings indefinitely. Since most businesses do not provide a deferred liability for the U.S. taxes that would result from the repatriation of foreign earnings, only a minimal effect of deferred liabilities would be expected.

Other financial statement accounts may also be affected. This could occur if, for example, the loss of deductibility for an item affects its market or net realizable value. ${ }^{5}$ The tax ramifications of a change from accrual to cash accounting for tax purposes may also have to be considered to the extent the change results in items being counted as an item of taxable income or expense either twice, or not at all. Retained earnings will be affected, either as a result of changes in the level of tax expense, or directly as an offset to any required changes in the deferred tax and other accounts.

For the purposes of this paper, effects resulting from the enactment of fundamental tax reform will be discussed in terms of their impact on retained earnings. Should (as is likely) the FASB determine that it is appropriate to reflect these changes in current earnings, any increase in retained earnings would be accompanied by an equivalent amount of income, and any decrease in retained earnings accompanied by an equivalent amount of expense. FAS 109 requires that the effect of a change in tax laws or rates be included in income from continuing operations for the period that includes the enactment date of the legislation.

\subsection{Limitations of the Financial-Accounting Approach}

The financial-statement effects of transition to a consumption-based tax system presented in section 3 below should be interpreted with caution for a variety of reasons. First, under generally accepted accounting principles (GAAP), the firm's tax accounts generally do not reflect consideration of the time value of money. Future tax costs and benefits are not discounted on the financial statement. Second, most assets (and liabilities) are not recorded at market value, but instead on the basis of historic cost (with adjustment for depreciation and amortization). Third, the value of many intangibles are not reflected in the balance sheet, such as

5 This is of particular concern for those assets, such as certain types of investunents and inventory, that must be carried for financial-accounting purposes at no more than market value. Assets used in the production process, such as depreciable plant and equipment, are not subject to this market-value limitation. Typically, the value at which these assets are carried for financial-accounting purposes must be reduced only if the nominal value of future cash flows attributable to the asset will not equal the asset's carrying value. 
self-created manufacturing and marketing intangibles, because marketing and research expenses generally are not permitted to be capitalized. Fourth, financial statements generally do not provide enough information to separate financial statement items between domestic and foreign operations at a detailed level. Finally, the effects of tax reform, as recorded in the financial statement, are based on the assumption of fixed prices. As a result, a financial statement measure of the impacts of tax reform must be regarded as a static analysis.

Despite the limitations of financial accounting data, we believe it is nevertheless important to examine the financial-statement effects of tax reform for three reasons. First, although the effect of tax reform on financial statements is unlikely to be a reliable indicator of stock market value changes, real business decisions will be affected by financialstatement changes. As noted by Martin Sullivan (1995, p. 207):

Because financial reporting is of critical importance to investors, creditors, bankers, appraisers, and regulators evaluating the financial soundness of firms, these impacts deserve careful consideration before adoption of any replacement consumption tax.

Second, support of the business community for fundamental tax reform may be difficult to garner if the financial statement effects are adverse for a large proportion of firms.

Third, financial statement data generally provide the most comprehensive publicly-available information on a firm's assets and liabilities, including income tax attributes such as net operating-loss carryforwards.

\section{TAX RESTRUCTURING PROPOSALS}

\subsection{National Retail Sales Tax}

\subsubsection{Overview}

Description of national retail sales tax The national retail sales tax, as proposed by Reps. Schaefer and Tauzin, would repeal the corporate and individual income taxes, the estate and gift taxes, and most federal excise taxes, and impose a new 15-percent national retail sales tax (NRST).

The Schaefer-Tauzin NRST is similar to retail sales taxes now imposed by 45 states, except that the NRST generally would exclude all business purchases and generally would apply to all services.

Under the NRST, businesses would pay tax equal to 15 percent of the gross amount received for sales of goods and services. Sellers would be required to provide an invoice with respect to taxable sales stating the 
amount of tax and certain other information. Sales to other businesses for resale or for use in the production of taxable goods and services would be exempt, as would exports.

Taxpayers would be allowed an administration credit equal to 0.5 percent of tax collected as well as a credit equal to 50 percent of the cost of equipment purchased to comply with the invoice requirement.

Employers would be required to pay each employee a "family consumption refund" equal to 15 percent of the lesser of the poverty level for the employee's family unit and the employee's annual compensation. The refund would be creditable against the employer's payroll tax.

Accounting for the national retail sales tax The replacement of the current income tax system with a system that imposes a national retail sales tax could eliminate the need to recognize income tax expense for financial statement purposes. If the replacement system is viewed by the Emerging Issues Task Force and the Financial Accounting Standards Board as a tax on the acquisition of goods and services, rather than a tax of income, the present financial accounting system could be replaced by a system where transactions are reported by the selling entity net of any tax effect. While such a net-of-tax system could still require the recognition of deferred and prepaid tax accounts, such accounts would not be related to the deferred income tax asset and liability accounts maintained under present accounting procedures. Instead they would reflect the difference between cash and accrual measure of sales-tax liability. Such an approach would be consistent with that taken by the financial accounting authorities of other countries, where a national sales tax or value-added tax represents a material part of the tax liability.

If tax expense need no longer be recognized for financial accounting, there is no need to continue to report either deferred income tax assets or liabilities. These accounts represent a measurement of future tax consequences. If tax consequences are no longer to be taken into consideration, there is nothing to measure.

Elimination of the deferred-tax accounts will affect retained earnings and potentially current income and expense. Elimination of a deferred income tax liability would increase retained earnings and potentially net income, while elimination of a deferred asset would have the opposite effect. Whether net income is affected will depend upon whether the FASB determines that it is appropriate to allow the elimination of the deferred-tax account to affect current earnings, or requires the effect to be taken directly to retained earnings. 
3.1.2 Financial-Statement Impact If replacement of the current income tax system with a national retail sales tax eliminates the need to recognize tax expense for financial statement purposes, thereby eliminating the need for the deferred tax accounts, the direct impact of enactment on any business can be estimated by treating the balance in any existing deferredtax-liability account as an increase to retained earnings and the balance in any existing deferred-tax-asset account as a decrease to retained earnings. This is the same effect that would be experienced if the income tax were simply repealed.

Data For purposes of this analysis, the financial statement effects of tax reform were calculated for a sample of 96 U.S. corporations across 12 selected industries. These include five major industrial divisions (agriculture; mining; construction; wholesale and retail trade; and transportation, communications, and utilities), six industry groups within the manufacturing division (food, paper, chemicals, petroleum, electronics, and transportation equipment), and the business services industry. The only major industrial division of the economy not included in this analysis is financial services, which would be subject to special rules under the various tax restructuring proposals. ${ }^{6}$

Within each of the 12 sectors, the eight largest public corporations were selected for which sufficiently detailed financial statement information was available for the 1995 reporting period. Financial data were obtained from SEC Form 10K information included in the Standard and Poors' Compustat database, and from the tax footnote provided in the annual financial statement. Given the small sample of companies in each industry (eight firms), the results presented may not be fully representative of each industry as a whole.

Aggregate results Overall, the financial statement effect of replacing the income tax with a 20-percent national retail sales tax is estimated to increase shareholders' equity by 5.6 percent, based on 1995 data, for the 96 firms in our sample (see Table 2 and Figure 1). This result does not include any impact from an increase in the price level that might occur as a result of this tax restructuring proposal. If the price level were to increase by 20 percent, the impact on shareholders, including the loss in purchasing power, would be a decline in shareholders' equity of 14.4

6 Some primarily nonfinancial companies, such as the "big 3 " automobile companies, have large financial subsidiaries. These subsidiaries would likely be subject to special rules under a consumption tax. For purposes of this analysis, however, financial subsidiaries are assumed to be taxed under the general rules. See Merrill and Edwards (1996). 
percent (5.6 percent less 20 percent). ${ }^{7}$ Because the balance sheet is not restated for changes in the price level under GAAP, the financial statement would not show the effect of such a price-level change.

At constant prices, the 5.6-percent increase in shareholders' equity amounts to $\$ 28.8$ billion for the sample of 96 companies. The largest component of the deferred-tax accounts of the sampled companies is the $\$ 88.3$ billion of deferred tax liability that is attributable to property and equipment (PP\&E) and arises from cost-recovery deductions (depreciation, depletion, and amortization) that have been taken into account for tax purposes, but remain to be taken into account for financial-accounting purposes. This amount represents the amount of taxes that have not yet been paid as a result of the more rapid cost recovery permitted for tax purposes.

Offsetting the elimination of the deferred tax liability for PP\&E is the loss of the deferred-tax assets recorded for other post-employment benefits (OPEB, at $\$ 46.8$ billion), credit carryforwards ( $\$ 8.2$ billion), and net operating loss (NOL) carryforwards ( $\$ 7.8$ billion).

OPEB relates primarily to medical and other expenses for retirees that have been accrued and deducted for book purposes but that will not be deducted for tax purposes until they are paid in the future. A portion of this amount may also represent employee-related restructuring costs that have been accrued for book but will not give rise to a tax deduction until some time in the future. Under present law, the deferred deductions for these items will result in reduced taxes in the future. Replacement of the income tax with a national sales tax eliminates these future tax savings. Because there would no longer be a future benefit, there would be no justification for the deferred-tax asset. Its elimination results in a decrease to shareholder's equity by an equivalent amount.

Results by industry On an industry basis, the impact on shareholders' equity (at constant prices) ranges from a decrease of 25.8 percent for the transportation equipment industry to increases of 20.5 and 21.7 percent for the petroleum and mining industries, respectively. The large decline in shareholders' equity in the transportation equipment industry is primarily attributable to $\$ 23.5$ billion of deferred-tax assets for OPEB liability, accounting for 27 percent of shareholders' equity. The large increase in shareholders' equity in the petroleum and mining industries is attributable to the elimination of deferred tax liabilities

${ }^{7}$ The Schaefer-Tauzin bill (H.R. 3039) proposes a tax-inclusive national RST rate of 15 percent, which is equivalent to a 17.65 -percent tax-exclusive rate. Neither the Treasury Department nor the Joint Committee on Taxation has published estimates regarding the tax rate necessary to ensure that H.R. 3039 would be revenue-neutral. 
associated with PP\&E, accounting for 25 and 36 percent of shareholders' equity, respectively. Under present law, both the petroleum and mining industries are allowed to recover certain exploration and development costs for tax purposes using methods that are more accelerated than are used for GAAP.

\subsection{Flat Tax With Maximum Transitional Relief}

\subsubsection{Overview}

Description of flat tax The flat tax would repeal the individual and corporate income taxes. The corporate income tax and the individual tax on unincorporated business income would be replaced by a new business tax applicable to all businesses regardless of legal form. Businesses generally would compute their flat-tax base by deducting from gross receipts the cost of most business expenses, including capital items. The cash method of accounting generally would be required under the flat tax. Initially, a 20-percent tax rate would be applied to the tax base. The rate would drop to 17 percent two years after enactment.

Dividends, interest, and income from the sales of financial assets would not be included in the tax base of nonfinancial companies. Symmetrically, dividend and interest payments would not be allowed as deductions under the flat tax for nonfinancial companies. Rent and royalty income would be includible in business receipts, while rent and royalty expenses would be deductible, as under the corporate income tax.

Capital purchases, including the entire cost of property, plant, and equipment, would be fully deducted in the year of purchase. Gross proceeds from sales of assets would be included in the flat-tax base. Depreciation, depletion, and amortization rules would be eliminated.

The flat tax is a territorial, origin-based tax. Income from foreign branches and dividends from foreign subsidiaries would be excluded. No deduction or credit would be allowed with respect to foreign income or withholding taxes. As under the income tax, gross receipts from exports would be included in the tax base, and the cost of imports would be deductible to the extent they represent business expenses.

The flat tax would not allow deductions for certain expenditures currently deducted for income tax purposes, such as non-cash employee compensation and benefits (other than contributions to a qualified retirement account), interest payments, and most tax payments. Losses could not be carried back to prior years, but could be carried forward to future years, and would be increased by interest (at the three-month Treasurybill rate). 
Flat-tax rate The Armey flat tax (H.R. 2060) proposed a 20-percent rate for two years, dropping to 17 percent thereafter. A December 20, 1995 Treasury Department study estimated that a 20.8-percent rate would be revenue-neutral at 1996 levels. The Treasury Department estimate assumed no changes in the aggregate level of economic activity, and did not take into account any transitional relief that might be provided. ${ }^{8}$ With transitional relief, a higher rate would be required for revenue neutrality. Hall and Rabushka (1995) estimate that the flat-tax rate would need to be 1.1 percentage points higher for about five years if Congress continued to allow depreciation deductions on existing assets to be taken after the effective date of the flat tax. ${ }^{9}$ If transitional relief were provided for other items, such as basis in inventory and loss carryforwards, an even larger tax rate increase would be necessary to maintain tax revenues. For the sake of example, a 20-percent flat tax rate is assumed in this analysis. Use of a higher tax rate would reduce (in absolute value) the magnitude of financial statement effects.

Accounting for the flat tax How the FASB would approach the replacement of the current income tax with the flat tax is not clear. The flat tax can be said to seek to replicate many of the economic effects of a sales or consumption tax, while retaining a modified measure of business income as its tax base. However, income, even though modified, continues to determine tax liability. While the economic effect of the restructured tax system could suggest that it be treated for financial-accounting purposes in the same manner as a national retail sales tax, the continued use of business income as the tax base could lead the FASB to retain a modified FAS 109-type approach should the flat tax be enacted.

The mechanics of an FAS 109-type system, should the FASB determine such an approach is appropriate following the enactment of the flat tax, are a matter of speculation. Generally, it may be expected that such a system would mirror the rules of FAS 109, unless there is an overriding reason to modify a rule.

Assuming that the new rules would generally mirror those set out in FAS 109, the required calculation would begin with the identification of temporary differences under the new law. Application of a re-determined tax rate to this amount of temporary differences would form the basis of the new measure of the deferred-tax account, adjusted for any necessary valuation allowances. If it were possible to design transition rules

${ }^{8}$ Rep. Armey has indicated that some form of transitional relief would likely be added to the bill as a part of the legislative process.

${ }^{9}$ Hall and Rabushka (1995, p. 116). 
that excluded all transactions already recorded for financial-accounting purposes from the application of the new tax system, other than the change in rate, no change in the amount of the temporary differences would be expected. The portion of the deferred-tax accounts attributable to temporary differences could be restated by multiplying their balances as of the date of enactment by the ratio of the new statutory tax rate to the old. ${ }^{10}$

An item of separate concern will be the transitional treatment of the portion of the deferred-tax asset that consists of carryforward items such as minimum tax credits, general business credits, foreign tax credits, and net operating losses. If these items are not allowed to reduce future taxes under the new system, their value will be lost and with it the balance in the deferred-tax-asset account they represent. On the other hand, if transitional rules are included that increase the likelihood that the benefit of these items will be received, the need for valuation allowances against them may be reduced or eliminated. Maximum transitional relief would be achieved if the value of all credit carryforwards were preserved and the only change in the valuation of net operating-loss carryforwards were the change in rates.

3.2.2 Financial-Statement Impact The impact of enacting any tax change where an FAS 109-type system continues to apply will be the difference between the balances in the tax accounts immediately before and after the enactment of the change.

If it were possible to design and enact a flat tax with this hypothetical maximum transitional relief, the deferred-tax accounts immediately after enactment would equal the amount of deductible temporary differences ${ }^{11}$ and net operating losses restated to the new rate, plus the existing amount of credit carryforwards. Assuming a prior rate of 35 percent and a new rate of 20 percent, the net change in shareholder's equity

10 This conclusion assumes that graduated income-tax rates do not apply or are not material with respect to the company. Since the majority of the benefits of graduated Federal income tax rates are recaptured between $\$ 100,000$ and $\$ 335,000$ of taxable income, this assumption is reasonable for the purposes of this study. However, certain industries enjoy permanent tax benefits (for example, depletion of excess basis in the mining industry) that are reflected for financial accounting through reduced tax rates. For industries with tax rates materially different then the statutory rate, the restatement should be done using the ratio of the new statutory rate to the effective rate currently used for financial-statement purposes.

11 Under FAS 109, deductible temporary differences are those temporary differences that result in deductible amounts when the related asset or liability is recovered or settled. For the purposes of this study, the deductible temporary differences are the amounts described in columns 3 through 6 of Table 1 . 
would be equal to 15 percent ( 35 percent less 20 percent) of the temporary differences not attributable to credit carryforwards. ${ }^{12}$

If maximum transitional relief applies, replacement of the federal income tax with the flat tax would increase shareholder's equity for sampled companies by an average of 3.1 percent (see Table 3 and Figure 2). This increase in shareholders' equity is less than that estimated for the retail sales tax (5.6 percent), under a constant-price assumption, primarily because the income tax rate is viewed as dropping to 20 percent rather than zero. Industry effects are approximately proportional to those under the retail sales tax scenario. ${ }^{13}$

\subsection{Flat Tax with No Transitional Relief}

3.3.1 Overview As noted above, the impact of enacting any tax change where an FAS 109-type system continues to apply will be the difference between the balances in the tax accounts immediately before and after the enactment of the change. Unless maximum transitional relief applies, there will be some change in the temporary differences that will have to be taken into account, as well as the rate to be applied. In addition, the absence of transitional relief could affect the balance in other accounts.

Enactment of a flat tax without transitional relief would have widespread ramifications for the calculation of the deferred tax account. No attempt has been made to model all of these effects; instead, our approach is to focus on a small number of the most important items, specifically:

1. Tax rate change

2. Unrecovered tax basis in PP\&E

3. Unrecovered tax basis in inventory

4. Deduction for OPEB and other employment-related liabilities

5. Transition from accrual to cash accounting

6. Net operating-loss carryforwards

7. Credit carryforwards

We first calculate the effect of the tax rate change, assuming maximum transition relief (as in the preceding case), and then examine the impact

12 A firm's applicable tax rate under FAS 109 is determined in a separate calculation and may not equal the top marginal federal income-tax rate (see footnote 10, supra).

13 The industry effects are not precisely proportional because a rate reduction does not affect the value of credit carryforwards. 
of eliminating transitional relief for items 2-7 above at the new tax rate (assumed to be 20 percent). ${ }^{14}$

PPEE and inventory Absent transition relief, the adjusted tax basis in property, plant, and equipment and inventory will never be recovered. The tax basis in PP\&E and inventory is not shown on the financial statement and consequently had to be estimated by multiplying the worldwide book basis by the ratio of domestic to worldwide assets, based on segment reporting included in the financial statement. Second, the difference between the domestic book and tax bases for these items was estimated by dividing the temporary differences reported for these items (as shown in the tax footnote) by the statutory tax rate of 35 percent. ${ }^{15}$ Third, the estimated difference between domestic book and tax bases was subtracted from the estimated domestic book basis to yield an estimate of the domestic tax basis.

$O P E B$ and other employment-related liabilities Absent transition relief, accrued post-retirement benefit expenses are assumed to be nondeductible under the flat tax, as the Armey bill specifically denies a deduction for employee compensation other than provided in cash or in the form of contributions to a qualified pension plan. Most OPEB liabilities are believed to be attributable to retiree health insurance; however, to the extent that a portion of OPEB represents unfunded pension liability, the reduction in shareholders' equity is overstated.

Cash accounting Under present law, most corporations are required to use the accrual method of accounting. The Armey flat tax ostensibly would require use of the cash receipts and disbursements method of accounting. Absent transition relief, a switch from accrual to cash ac-

14 The valuation allowance is held constant in this analysis. To the extent that a portion of the valuation allowance is attributable to any of the separately considered deferred tax assets (NOL carryforwards, credit carryforwards, and OPEB expense), the loss of these deferred tax assets (absent transitional relief) would be offset by a reduction in the valuation allowance. Consequently, the estimates in this section may overstate the reduction in shareholders' equity (or understate the increase in shareholders' equity).

15 The temporary difference recorded for PP\&E primarily relates to differences in domestic tax basis. Generally there is little difference between U.S. financial and tax accounting for foreign PP\&E (as accelerated tax methods are not permitted). Much of the difference between book and tax accounting measures of inventory is depreciation-related, supporting a similar assumption that book-tax differences relate to domestic inventory. Further, since deferred taxes need not be provided for the earnings of foreign affiliates that are not indefinitely reinvested overseas, only a minor portion of temporary differences recognized in the financial statement should relate to foreign activity. 
counting would cause accrued but unreceived income items to be taxed twice, and accrued but unpaid expenses to be deducted twice. In addition, paid but unaccrued expenses (i.e., prepaid expenses) would never be deducted. The financial statement impact of this accounting-method change is estimated, using a 20-percent tax rate, based on the excess of trade receivables and prepaid expenses over the sum of accounts payable and accrued expenses. ${ }^{16}$

Net operating losses and credits Absent transitional relief, net operating loss and credit carryforwards will not be available for use after the enactment of the flat tax. Any deferred tax asset relating to these items would have to be eliminated, and shareholders' equity reduced by an equivalent amount.

3.3.2 Financial Statement Impact We first examine the financialstatement impact of adopting a 20-percent flat tax without transition rules and without regard to the potential effects of a switch from accrual to cash accounting.

Aggregate results The financial statement impact of implementing a 20-percent flat tax without transitional relief for the sampled companies is estimated to result in a decline in shareholders' equity of 19.0 percent (see Table 4 and Figure 3). By comparison, adoption of a 20-percent flat tax with maximum transition relief is estimated to result in a 3.1-percent increase in shareholders' equity (see section 3.2 above). For the sample of 96 firms examined in this study, the difference in shareholders' equity attributable to full transition relief is $\$ 113$ billion. A reconciliation of this difference in financial-statement impact is shown in Table 1.

Results by industry On an industry basis, the impact of the flat tax without transition rules on shareholders' equity (at constant prices) ranges from a decrease of 53.8 percent in the transportation equipment industry to a slight increase of 0.1 in the petroleum industry. The transportation equipment industry does not benefit from a tax rate reduction, due to a net deferred-tax-asset position, and shareholder equity is fur-

${ }_{16}$ This estimate may be inaccurate to the extent that book and tax accounting for these items differ under present law. For example, some expenses for book purposes may not be deductible for tax purposes until "economic performance" occurs [see Code section 461(h)]. For these expenses, no double deduction would occur, and the estimated reduction in owners' equity would be understated. Some accrued expenses (e.g., property taxes) may not be deductible under the flat-tax rules, which also would cause the estimated reduction in owners' equity to be understated. 


\section{TABLE 1}

Reconciliation of Financial Statement Impact: 20-percent Flat Tax with and without Transition Relief(a)

\begin{tabular}{lcr}
\hline & \multicolumn{2}{c}{ Change in shareholders' equity } \\
\cline { 2 - 3 } Item & Amount $(\$$ million $)$ & Percent \\
\hline $20 \%$ flat tax, maximum transition relief: & 15,882 & 3.1 \\
Net operating losses & $-4,433$ & -0.9 \\
Credit carryforwards & $-8,233$ & -1.6 \\
Basis in PP\&E & $-52,020$ & -10.2 \\
Basis in inventory & $-21,451$ & -4.2 \\
OPEB & $-26,728$ & -5.2 \\
$20 \%$ flat tax, no transition relief(b) & $-96,982$ & -19.0 \\
\hline
\end{tabular}

(a)Based on sample of 96 corporations; 1995.

(b) Excludes potential impact on cash accounting.

ther reduced by the inability to deduct OPEB expenses and the tax basis in PP\&E. The absence of any adverse effect on shareholders' equity in the petroleum industry results from the fact that the loss of NOLs, credit carryforwards, unrecovered tax basis, and OPEB deductions is offset by the large benefit obtained from a tax rate reduction on the deferred tax liability attributable to PP\&E.

Cash accounting Absent transition relief, assuming a 20-percent tax rate, the financial statement impact of changing to the cash method of accounting is estimated to by itself reduce shareholders' equity by 7.6 percent (see Table 5 and Figure 4). This large reduction in shareholders' equity may not have been intended, as it is not clear that the drafters of the Armey bill specifically considered the implications of switching from the accrual to the cash method of accounting. If the drafters of the flat tax intend this result, the electronics and transportation equipment industries would be particularly hard hit, each losing approximately 28 percent of shareholders' equity as a result of the accounting-method change. Including the effect of cash accounting, a 20-percent flat tax is estimated to reduce shareholders' equity in the transportation equipment industry by more than 80 percent, absent transition relief.

\section{CONCLUSIONS}

Using 1995 data for a sample of 96 firms in 12 industries, we estimate that adoption of a 20-percent flat tax without transitional relief would 
reduce shareholders' equity by an average of 19 percent, excluding the potential effects of a switch from accrual to cash accounting. There is considerable variation in the financial statement impact among industries: in one industry, the flat tax reduces shareholders' equity by over 50 percent, excluding the effect of cash accounting, and by over 80 percent including the effect of cash accounting. While there is considerable variation in financial statement effects within industries, differences in industry effects are statistically significant at the 1-percent level, except for the effect of switching from cash to accrual accounting (Table 5).

The financial statement impact of fundamental tax reform may overstate the decline in wealth because inflation and the time value of money generally are not taken into account, but may understate the decline in wealth due to static price assumptions inherent in financial accounting. Despite these and other limitations, the financial statement impact of tax reform proposals will be of considerable importance to the business community.

In practice, it may be difficult to design rules that precisely eliminate transitional wealth effects, for at least three reasons. First, asset values would both increase and decrease as a result of tax reform. Providing relief for losses in asset values, with no offsetting adjustment for windfall gains, would cause large losses in tax revenues, and would not necessarily achieve any sensible equity objective.

Second, the amount of transition relief required to eliminate windfall losses is difficult to gauge, because asset value changes depend on the speed at which the market adjusts to the post-reform equilibrium. If the adjustment process is slow, asset value declines generally will be smaller, requiring less transitional relief.

Third, the provision of transition relief to businesses cannot address wealth effects that are not borne by equity owners. For example, a decline in the real value of assets due to an increase in the price level under the national retail sales tax will affect domestic bondholders as well as domestic shareholders (but not foreign shareholders). Transition relief provided at the business entity level would not provide compensation to bondholders, but would overcompensate foreign shareholders.

Notwithstanding the difficulties in designing appropriate transition rules, it should be noted that the failure to provide transition rules that eliminate wealth losses would encourage taxpayers to delay or accelerate transactions between the current and anticipated tax systems to avoid losses and capture arbitrage gains. A gradual phase-in to a new tax system would moderate transitional wealth effects, but would add significant complexity and would increase opportunities for tax arbitrage. 


\section{REFERENCES}

Bradford, David F. (1996). "Consumption Taxes: Some Fundamental Transition Issues." In Frontiers of Tax Reform, Michael J. Boskin (ed.). Stanford: Hoover Institution.

Gravelle, Jane (1995). "The Flat Tax and Other Tax Proposals: Who Will Bear the Tax Burden?". Congressional Research Service. November 29. CRS Report for Congress 95-1141E.

Hall, Robert (1996). "The Effect of Tax Reform on Prices and Asset Values," in Tax Policy and the Economy; vol. 10, James M. Poterba (ed.). Cambridge: MIT Press.

Hall, Robert, and Alvin Rabushka (1995). The Flat Tax. 2nd ed.

Lyon, Andrew, Peter Merrill, MelbertSchwarz, and Chris Edwards (1997). "Business Transition Issues in Fundamental Tax Reform." Presented at the NBER conference on Asset Prices and Transition Effects of Consumption Tax Reform. January 27.

Merrill, Peter, and Chris Edwards (1996). "Cash-flow Taxation of Financial Services." National Tax Journal 49(3, September):487-500.

Sullivan, Martin A. (1995). Flat Taxes and Consumption Taxes: A Guide to the Debate. Washington: American Institute of Certified Public Accountants. 


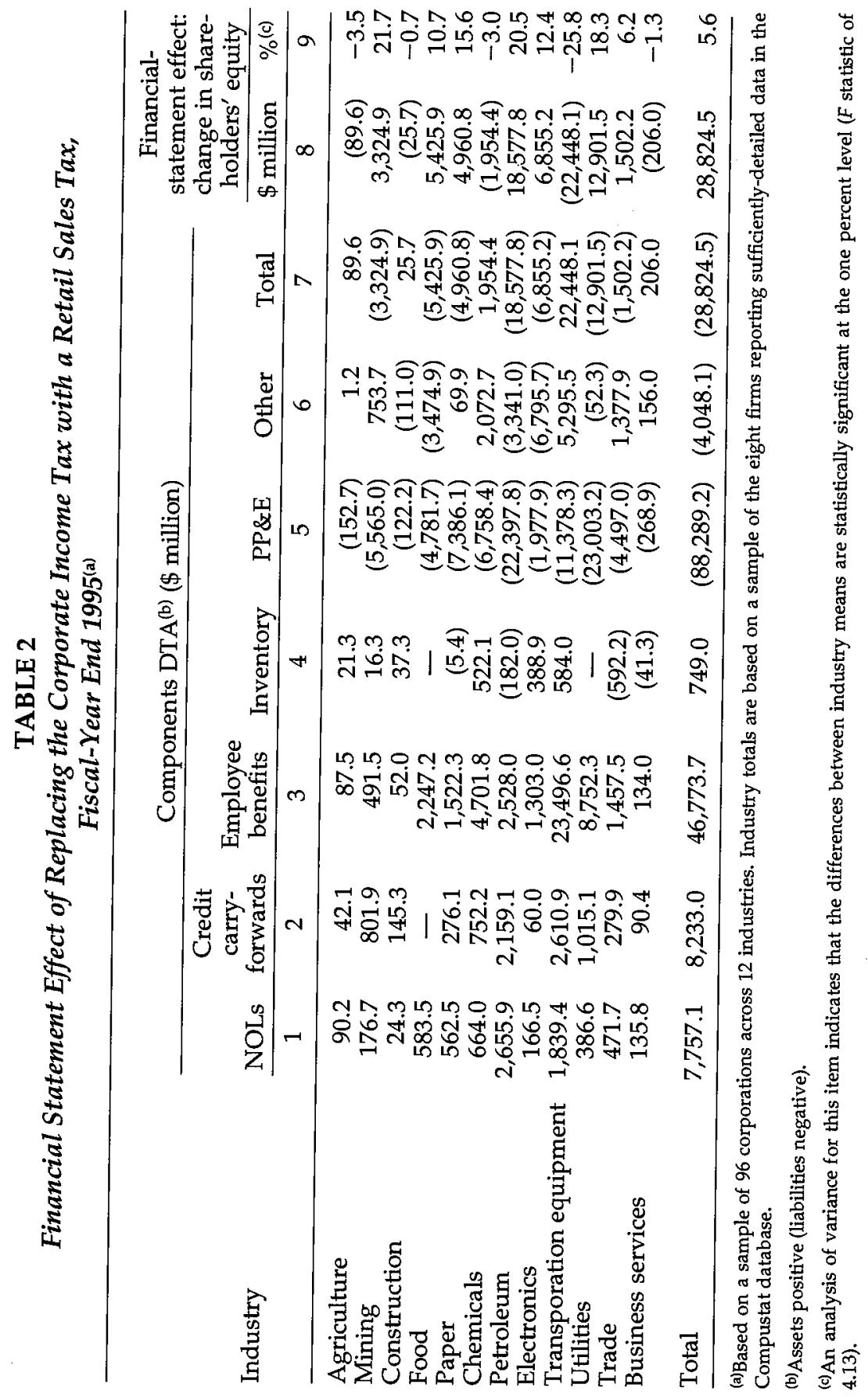




\section{TABLE 3}

Financial-Statement Effect of Replacing the Corporate Income Tax with a 20\% Flat Tax (Maximum Transition Relief), Fiscal-Year End 1995(a)

\begin{tabular}{|c|c|c|c|c|}
\hline \multirow{4}{*}{ Industry } & \multicolumn{2}{|c|}{ Items ( $\$$ million) } & \multirow{2}{*}{\multicolumn{2}{|c|}{$\begin{array}{l}\text { Financial-statement } \\
\text { effect: change in } \\
\text { shareholders' equity }\end{array}$}} \\
\hline & \multirow{2}{*}{$\begin{array}{c}\text { Temporary } \\
\text { differences }^{(b)} \\
@ 15 \% \\
\end{array}$} & \multirow{2}{*}{$\begin{array}{l}\text { NOLs } \\
@ 15 \%\end{array}$} & & \\
\hline & & & $\$$ million & $\%(c)$ \\
\hline & 1 & 2 & $3=-(1+2)$ & 4 \\
\hline Agriculture & (18.3) & 38.7 & $(20.4)$ & -0.8 \\
\hline Mining & $(1,844.4)$ & 75.7 & $1,768.6$ & 11.5 \\
\hline Construction & (61.7) & 10.4 & 51.3 & 1.4 \\
\hline Food & $(2,575.5)$ & 250.1 & $2,325.4$ & 4.6 \\
\hline Paper & $(2,485.4)$ & 241.1 & $2,244.4$ & 7.1 \\
\hline Chemicals & 230.7 & 284.6 & $(515.2)$ & -0.8 \\
\hline Petroleum & $(10,025.5)$ & $1,138.2$ & $8,887.2$ & 9.8 \\
\hline Electronics & $(3,035.0)$ & 71.4 & $2,963.7$ & 5.4 \\
\hline $\begin{array}{l}\text { Transportation } \\
\text { equipment }\end{array}$ & $7,713.3$ & 788.3 & $(8,501.7)$ & -9.8 \\
\hline Utilities & $(6,129.9)$ & 165.7 & $5,964.3$ & 8.4 \\
\hline Trade & $(965.9)$ & 202.2 & 763.8 & 3.2 \\
\hline Business services & (8.7) & 58.2 & $(49.5)$ & -0.3 \\
\hline Total & $(19,206.2)$ & $3,324.5$ & $15,881.8$ & 3.1 \\
\hline
\end{tabular}

(a)Based on a sample of 96 corporations across 12 industries. Industry totals are based on a sample of the eight largest firms reporting sufficiently-detailed data in Compustat.

(b) Temporary differences here refer to the total deferred tax account less NOL and credit carryforwards.

(c) An analysis of variance for this item indicates that the differences between industry means are statistically significant at the $1 \%$ level (F statistic of 3.96 ). 


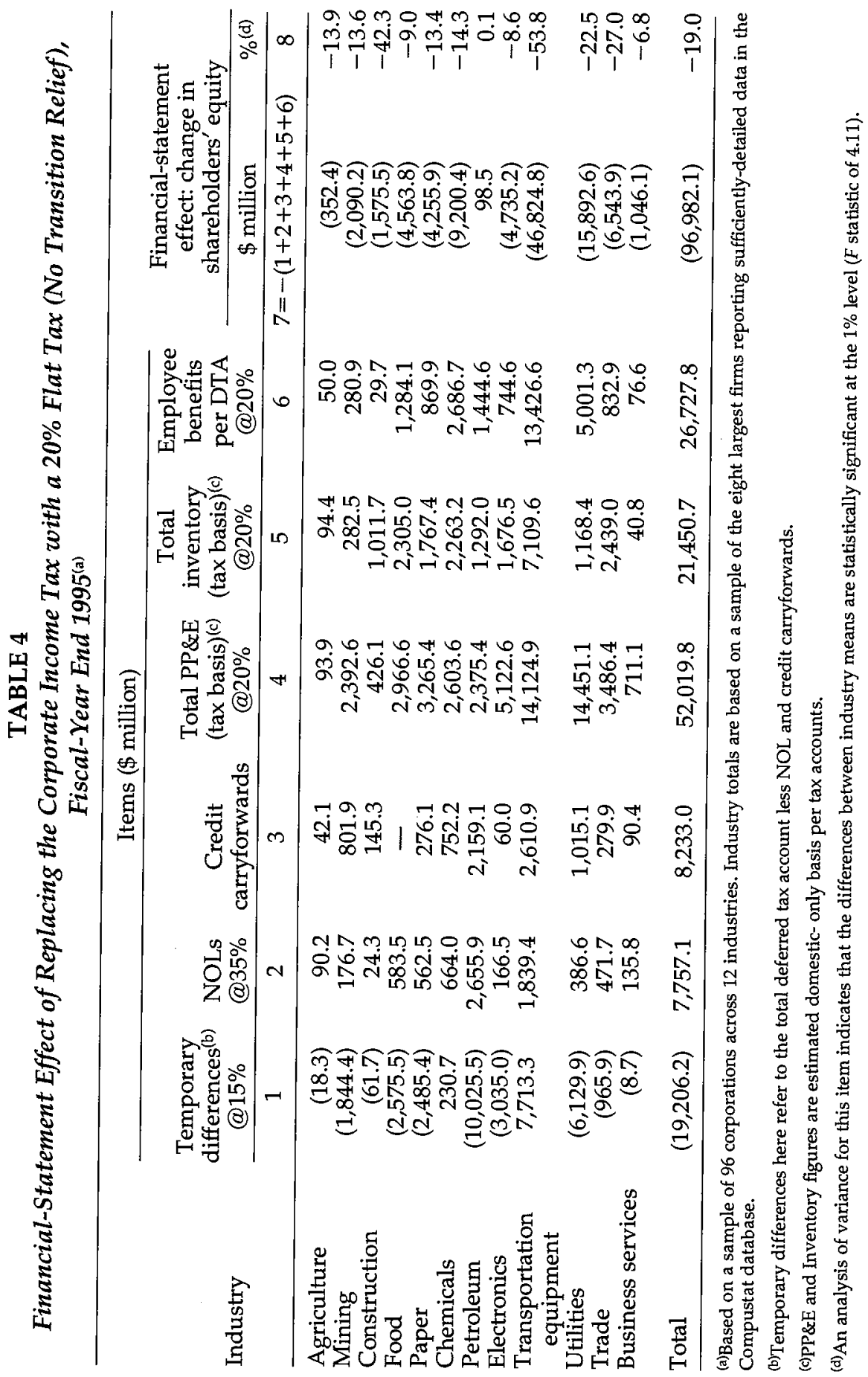




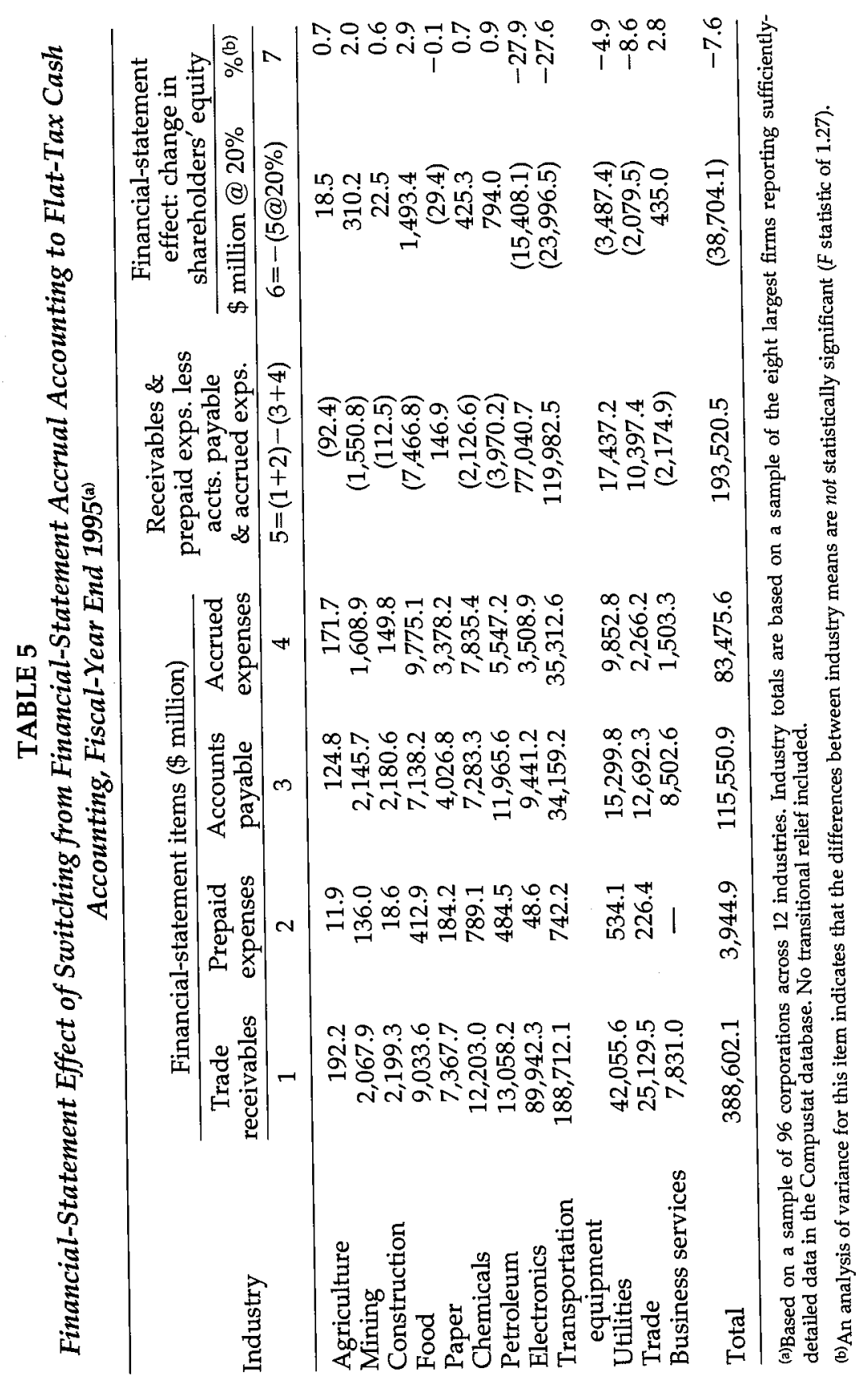




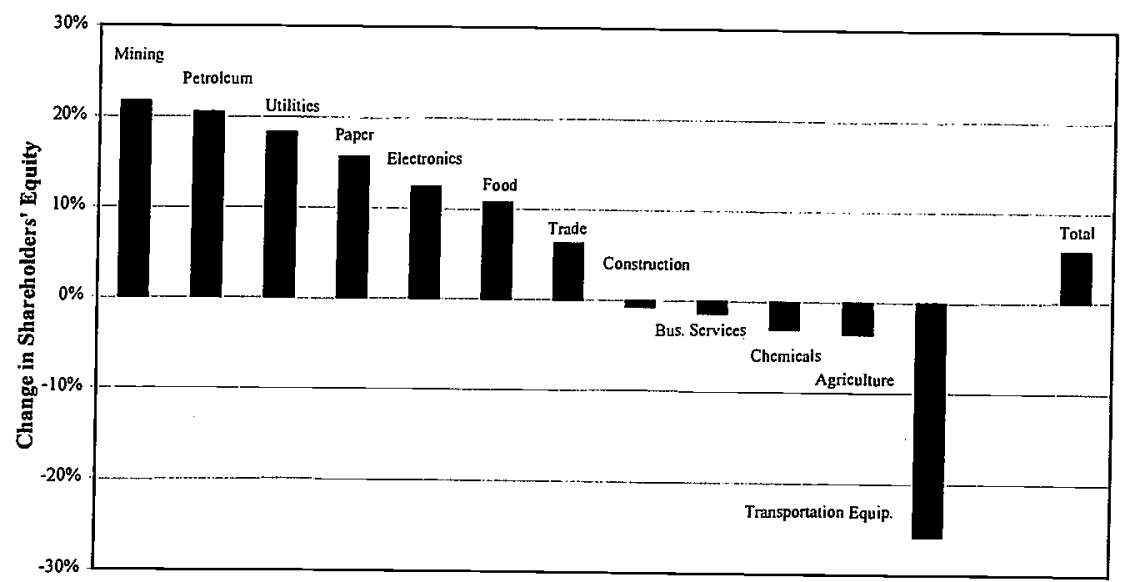

FIGURE 1: Financial-Statement Effect of Replacing the Corporate Income Tax with a Retail Sales Tax, 1995

Source: Table 2.

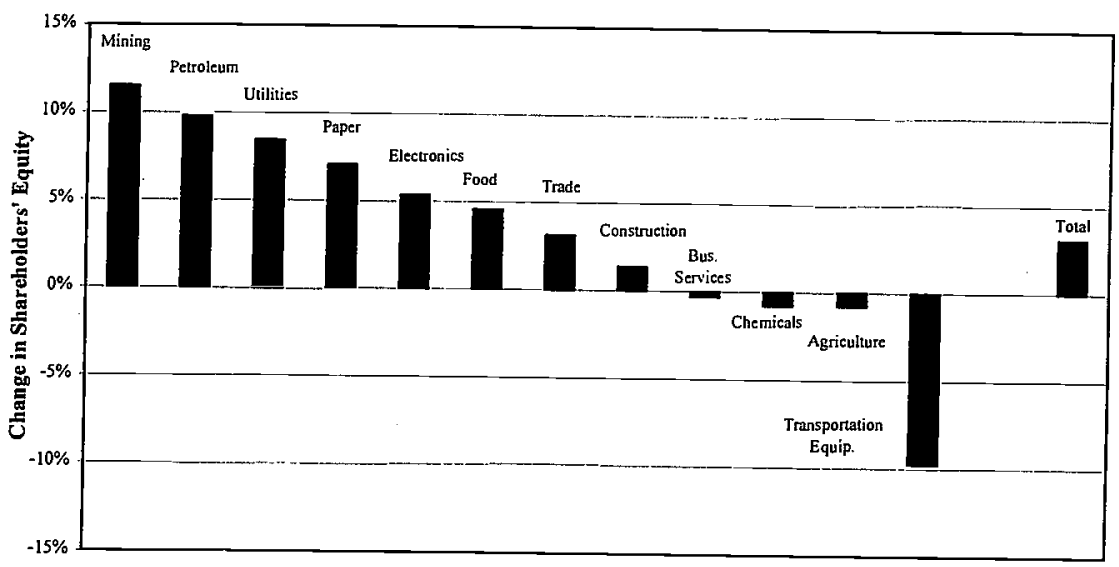

FIGURE 2: Financial-Statement Effect of Replacing the Corporate Income Tax with a Flat Tax (Maximum Transition Relief), 1995

Source: Table 3 . 


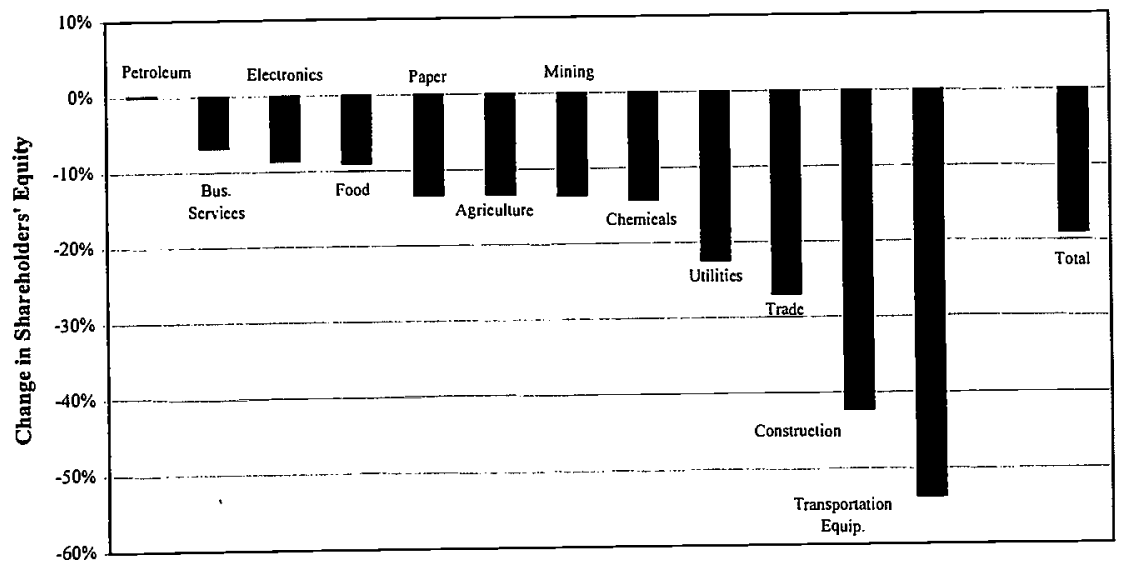

FIGURE 3: Financial-Statement Effect of Replacing the Corporate Income Tax with a Flat Tax (No Transition Relief), 1995

Source: Table 4.

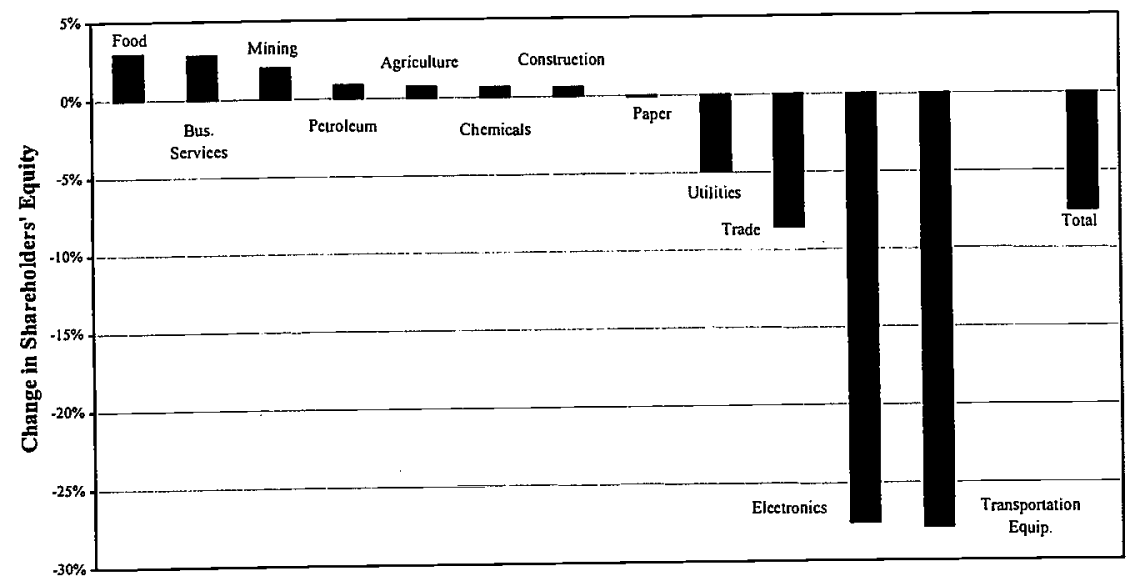

FIGURE 4: Financial-Statement Effect of Switching from Accrual to Cash Accounting under the Flat Tax, 1995

Source: Table 5. 